\title{
Tumor-specific $\mathrm{CD4}^{+} \mathrm{T}$ cells develop cytotoxic activity and eliminate virus-induced tumor cells in the absence of regulatory $T$ cells
}

\author{
Ilseyar Akhmetzyanova - Gennadiy Zelinskyy • \\ Simone Schimmer - Sven Brandau • \\ Petra Altenhoff · Tim Sparwasser · Ulf Dittmer
}

Received: 1 March 2012/ Accepted: 25 July 2012/Published online: 14 August 2012

(C) The Author(s) 2012. This article is published with open access at Springerlink.com

\begin{abstract}
The important role of tumor-specific cytotoxic $\mathrm{CD} 8^{+} \mathrm{T}$ cells is well defined in the immune control of the tumors, but the role of effector $\mathrm{CD}^{+}{ }^{+} \mathrm{T}$ cells is poorly understood. In the current research, we have used a murine retrovirus-induced tumor cell line of C57BL/6 mouse origin, namely FBL-3 cells, as a model to study basic mechanisms of immunological control and escape during tumor formation. This study shows that tumor-specific $\mathrm{CD}^{+} \mathrm{T}$ cells are able to protect against virus-induced tumor cells. We show here that there is an expansion of tumor-specific $\mathrm{CD}^{+} \mathrm{T}$ cells producing cytokines and cytotoxic molecule granzyme $\mathrm{B}(\mathrm{GzmB})$ in the early phase of tumor growth. Importantly, we demonstrate that in vivo depletion of regulatory $\mathrm{T}$ cells (Tregs) and $\mathrm{CD} 8^{+} \mathrm{T}$ cells in FBL-3-bearing DEREG transgenic mice augments IL-2 and GzmB production by $\mathrm{CD} 4^{+} \mathrm{T}$ cells and increases $\mathrm{FV}$-specific $\mathrm{CD}^{+}{ }^{+} \mathrm{T}$-cell effector and cytotoxic responses leading to the complete tumor regression. Therefore, the
\end{abstract}

Electronic supplementary material The online version of this article (doi:10.1007/s00262-012-1329-y) contains supplementary material, which is available to authorized users.

I. Akhmetzyanova $(\bowtie) \cdot$ G. Zelinskyy $\cdot$ S. Schimmer ·

U. Dittmer

Institute for Virology, University of Duisburg-Essen,

Virchowstr 179, 45147 Essen, Germany

e-mail: ilseyar.akhmetzyanova@uni-due.de

U. Dittmer

e-mail: ulf.dittmer@uni-due.de

S. Brandau $\cdot$ P. Altenhoff

Department of Otorhinolaryngology, University Clinics Essen, 45122 Essen, Germany

T. Sparwasser

Institute for Infection Immunology, TWINCORE,

Feodor-Lynen-Str. 7, 30625 Hannover, Germany capacity to reject tumor acquired by tumor-reactive $\mathrm{CD} 4^{+}$ $\mathrm{T}$ cells largely depends on the direct suppressive activity of Tregs. We suggest that a cytotoxic $\mathrm{CD} 4^{+}$T-cell immune response may be induced to enhance resistance against oncovirus-associated tumors.

Keywords Tumor immunity · Viral oncogenesis · Effector $\mathrm{CD}^{+}{ }^{+} \mathrm{T}$ cells $\cdot$ Regulatory $\mathrm{T}$ cells

\section{Introduction}

The majority of tumor viruses are well controlled by the immune system and therefore cause only transient or no disease in their hosts after infection. It is apparent that the main role in this control can be ascribed to the presence of cytotoxic $\mathrm{CD}^{+} \mathrm{T}$ cells, which are very effective in destroying virus infected or transformed cells. In recent years, the idea that $\mathrm{CD} 4^{+} \mathrm{T}$ cells can also play a considerable role in protective anti-tumor responses has received growing attention. One important function of $\mathrm{CD} 4^{+} \mathrm{T}$ cells is their help for $\mathrm{CD}^{+} \mathrm{T}$ cell and antibody responses against virus or tumor antigens. However, studies using several tumor models have shown that $\mathrm{CD}^{+} \mathrm{T}$ cells can efficiently eliminate major histocompatibility complex (MHC) class II expressing tumor cells $[1,2]$ as well as tumors lacking MHC class II molecules [3-5], demonstrating a direct role of $\mathrm{CD}^{+} \mathrm{T}$ cells in tumor rejection. However, whether $\mathrm{CD} 4^{+} \mathrm{T}$ cells can fully compensate for the effector functions of $\mathrm{CD} 8^{+} \mathrm{T}$ cells in the control of virus-induced tumors remains unclear. In addition, the significance of regulatory $\mathrm{T}$ cells (Tregs) in inhibiting tumor-specific $\mathrm{CD} 4^{+} \mathrm{T}$-cell responses during tumor rejection in vivo has not been defined. It was previously reported that Tregs infiltrate tumors and draining lymph 
nodes, suggesting that they interfere with anti-tumor immune responses in general and thereby contribute to tumor growth and progression [6]. Tregs inhibit the function of many adaptive and innate immune cells, including $\mathrm{CD}^{+}{ }^{+} \mathrm{T}$ cells, $\mathrm{CD}^{+} \mathrm{T}$ cells, dendritic cells (DCs), macrophages, natural killer (NK) cells, and B cells through various molecular mechanisms [7]. To define the role of Tregs in tumor immunity, most studies have used malignant tumor models, in which the immune system failed to prevent tumor progression. However, the task of effector $\mathrm{CD}^{+} \mathrm{T}$ cells and Tregs should also be analyzed in effective anti-tumor immunity to fully understand their role in tumor biology.

To address these questions, we have used the Friend retrovirus (FV)-induced mouse tumor cell line of C57BL/6 origin, called FBL-3 cells [8]. This cell line was generated by inoculation of FV complex into mice, which results in an EPO receptor-dependent proliferation signal in erythroid precursor cells. Integration of pro-virus can subsequently cause over-expression of the Spil proto-oncogene and inactivation of the $p 53$ tumor suppressor gene resulting in host cell transformation. Thus, FV infection can induce fully malignant erythroleukemia in susceptible mouse strains. FBL-3 is a FV-transformed tumor cell line that does not produce infectious virus, but expresses highly immunogenic FV antigens [9, 10]. After subcutaneous (s.c.) implantation of FBL-3 cells into mice, the tumor grows locally and subsequently regresses in a $\mathrm{CD} 8^{+} \mathrm{T}$-celldependent manner over a time period of 20 days [11, 12]. Tumor-specific $\mathrm{CD} 4^{+} \mathrm{T}$ cells seem to be less important for tumor rejection when functional $\mathrm{CD}^{+} \mathrm{T}$ cells are present [13]. However, if the pool of Tregs is expanded by a chronic infection, mice fail to reject transplants of FBL-3 tumors due to a Treg-mediated suppression of tumor-specific $\mathrm{CD}^{+} \mathrm{T}$-cell responses [11]. In the present study, we used Foxp3 (forkhead box P3) transgenic mice expressing the diphtheria toxin (DT) receptor under the control of the Foxp3 promoter, which made it possible to selectively deplete Tregs in vivo and to determine the influence of Foxp $3^{+}$Tregs on T-cell responses during tumor regression. We especially focused on the direct anti-tumor effect of $\mathrm{CD}^{+} \mathrm{T}$ cells and found that these cells could fully compensate for the lack of cytotoxic $\mathrm{CD}^{+} \mathrm{T}$ cells when their functional suppression by Tregs was interrupted.

\section{Materials and methods}

Mice

Experiments were done using sex- and age-matched C57BL/6 (B6), CD45.1, and DEREG [14] mice that were between 8 and 10 weeks old when experiments started. Mice were housed in specific pathogen-free conditions and treated in accordance with institutional guidelines.

\section{Cell lines}

FBL-3 is an FV-induced tumor cell line derived from a C57BL/6 mouse [8]. The highly immunogenic FBL-3 cell line expresses $\mathrm{FV}$ antigens but does not produce infectious virus. FBL-3 cells were maintained in complete RPMI medium supplemented with $10 \%$ FCS and $0.5 \%$ penicillin/streptomycin.

Tumor challenge

$1 \times 10^{7}$ FBL-3 tumor cells were injected s.c. on the right flank in $100 \mu$ of PBS through a 27-gauge needle on day 0 . In order to verify tumor volume by external caliper, the greatest longitudinal diameter (length) and the greatest transverse diameter (width) were determined. Tumor size based on caliper measurements was calculated by the formula: tumor area $\left(\mathrm{cm}^{2}\right)=\pi \times a \times b$, where $a=$ half of length and $b=$ half of width. After 4, 6, 8, 11, 15, and 20 days, mice were killed, and tumors and draining and non-draining lymph nodes were resected.

In vivo cell depletion

CD8 depletion was performed as described [15] and started at day 0 and carried out every other day for the tumor growth analysis until mice were killed due to the progressive tumor growth, and four times (on days 0, 2, 4, 6) for the experiments where mice were killed at day 6 posttumor inoculation. Depletion of Tregs was done as described [16] and started at day 1 for three times. Depletion of $\mathrm{CD}^{+} \mathrm{T}$ cells was performed as described [17] and started at day 0. Deletion of NK cells was carried out as described [15].

Staining and flow cytometry

Antibodies used for cell-surface staining were anti-CD4 (AF 700-conjugated, GK 1.5), anti-CD8a (eFluor 450conjugated, 53-6.7), anti-CD43 (PerCP-conjugated, 1B11), anti-CD25 (PE Cy7-conjugated, PC61.5), anti-Mac-1 (antiCD11b) (FITC-conjugated, WT.5), anti-F4/80 (PE-conjugated, BM8), anti CD86 (eFluor 605-conjugated, GL-1), and Fc block anti-mouse CD16/CD32 (93) (eBioscience). Dead cells were excluded by using propidium iodide. Intracellular granzyme B (GzmB) staining was performed as described [18]. To determine intracellular production of interferon- $\gamma$ (IFN- $\gamma)$, tumor necrosis factor- $\alpha$ (TNF- $\alpha$ ) and interleukin-2 (IL-2) cells from lymph nodes were 
stimulated in the presence of $2 \mu \mathrm{g} / \mathrm{ml}$ of CD28 antibody and $2 \mu \mathrm{g} / \mathrm{ml}$ of brefeldin A for $5 \mathrm{~h}$ at $37{ }^{\circ} \mathrm{C}$. The cells were then stained for surface expression of CD4, CD8, and CD43, fixed, and permeabilized with Cytofix/Cytoperm solution (BD). The cells were then washed, permeabilized, and incubated with Fc blocking anti-mouse CD16/CD32. After that, cells were labelled with monoclonal antibodies specific for IL- 2 , IFN- $\gamma$, TNF- $\alpha$, and anti-CD154. In addition to cytokines, cells were labeled with anti-CD154 (PEconjugated, CD40Ligand, gp39, MR1). Foxp3 expression was detected by intracellular staining using an anti-mouse/ rat Foxp3 antibody (FITC-conjugated, FJK-16s) and the Foxp3 staining kit (eBioscience). Helios expression was measured by intracellular staining using an anti-mouse/ human Helios antibody (eFluor 450-conjugated, 22F6, BioLegend) and the Foxp3 staining kit (eBioscience). Dead cells were excluded by using Fixable Viability Dye (eBioscience). Data were acquired on an LSRII flow cytometer (Becton-Dickinson) from 200,000 to 500,000 lymphocyte-gated events per sample. Analyses were done using FACSDiva software (Becton-Dickinson) and FlowJo software (Treestar).

In vivo cytotoxicity

The in vivo cytotoxicity assay was done as it was described by Barber et al. [19]. Tumor-bearing DEREG mice were depleted or not depleted for their Treg and $\mathrm{CD}^{+} \mathrm{T}$ cells. Six days after tumor challenge, all groups of mice received Carboxyfluorescein succinimidyl ester (CFSE)-labeled lymphocyte targets loaded with peptide [20] as well as unloaded unstained cells from CD45.1 mice as a control population. $2 \mathrm{~h}$ after intravenous (i.v.) injection of donor cells, mice were killed and in vivo killing activity was quantified in single-cell suspensions from the drLN of each tumor-bearing mouse.

\section{Immunohistochemistry}

Tumors were dissected sharply using surgical scissors, immediately shock-frozen in liquid nitrogen and stored at $-80{ }^{\circ} \mathrm{C}$. The frozen tissues were sectioned in $5 \mu \mathrm{m}$ slices, placed on slides, air-dried, and stained with hematoxylineosin.

Frozen samples were air-dried and fixed with Cytofix/ Cytoperm (BD, Heidelberg, Germany). Endogenous peroxidase activity was blocked with Dako REAL PeroxidaseBlocking solution (DakoCytomation, Hamburg, Germany) followed by several washing steps with PBS. Slides were incubated for $60 \mathrm{~min}$ with the primary monoclonal rat antimouse antibodies anti-CD11b antibody (BioSource, Solingen, Germany) or anti-CD4 antibody (BD Bioscience, Heidelberg, Germany). Subsequently, samples were incubated with peroxidase-conjugated rabbit anti-rat (Dianova, Hamburg, Germany) and goat anti-rabbit antibodies (Dianova) for 30 min each and AEC Single Solution (Invitrogen). Nuclei were visualized by Shandon Instant Hematoxylin (Thermo Fisher Scientific). Sections were analyzed with a Zeiss Axioscope 2 (Carl Zeiss, Oberkochen, Germany) using objective lenses with $200 \times$ magnification and AxioVision software (Zeiss).

\section{Tetramer staining}

MHC class I and class II tetramer staining was performed as described [17].

Statistical analyses

Statistical analyses and graphical presentations were computed with Graph Pad Prism version 5. Statistical differences ( $P$ value) between two groups were calculated using unpaired t test. Statistical differences ( $P$ value) between the different parameters were calculated testing with the Kruskal-Wallis one-way analysis of variance on ranks and Newman-Keuls multiple comparison tests.

\section{Results}

Kinetics of the antigen-specific $\mathrm{CD} 4^{+}$and $\mathrm{CD} 8^{+} \mathrm{T}$-cell response in lymph nodes during tumor rejection

To study $\mathrm{T}$-cell responses in tumor cell rejection, we used the leukemia cell line FBL-3, a FV-induced tumor line from a C57Bl/6 mouse. These highly immunogenic murine leukemia cells induce local tumor growth after s.c. injection into C57/B16 mice for about 20 days before being rejected due to IFN- $\gamma$ and granzyme-producing $\mathrm{CD}^{+}$T cells [11]. It has been shown that FBL-3 tumor cells express $\mathrm{FV}$ antigens that can be recognized by $\mathrm{CD}^{+}$and $\mathrm{CD}^{+} \mathrm{T}$ cells $[9,10]$. To determine the kinetics of T-cell responses in this tumor rejection model, we quantified the population of $\mathrm{FV}$-specific effector $\mathrm{CD}^{+} \mathrm{T}$ cells by staining lymphocytes from draining $(\mathrm{drLN})$ and non-draining lymph nodes (non-drLN) of FBL-3-challenged mice with H-2D ${ }^{\mathrm{b}}$ gagL MHC class I tetramers $[9,20]$ or MHC class II tetramers loaded with the $\mathrm{H}-2 \mathrm{I}-\mathrm{A}^{\mathrm{b}}$-restricted $\mathrm{CD}^{+}{ }^{+} \mathrm{T}$-cell epitope H19-Env [20]. Early after tumor challenge (4 days post-tumor challenge (ptc)), expansion of specific cells was only found in the $\mathrm{CD}^{+}$but not the $\mathrm{CD} 8^{+} \mathrm{T}$-cell population (Fig. 1a, b). Thus, the frequencies of antigen-specific $\mathrm{CD}^{+}{ }^{+} \mathrm{T}$ cells in drLN at day 4 ptc were significantly higher compared to specific $\mathrm{CD}^{+} \mathrm{T}$ cells (Fig. 1c). Peak expansion of specific $\mathrm{CD}^{+}{ }^{+} \mathrm{T}$ cells was found as early as at 6 days post-tumor challenge, whereas $\mathrm{CD}^{+}$T-cell 

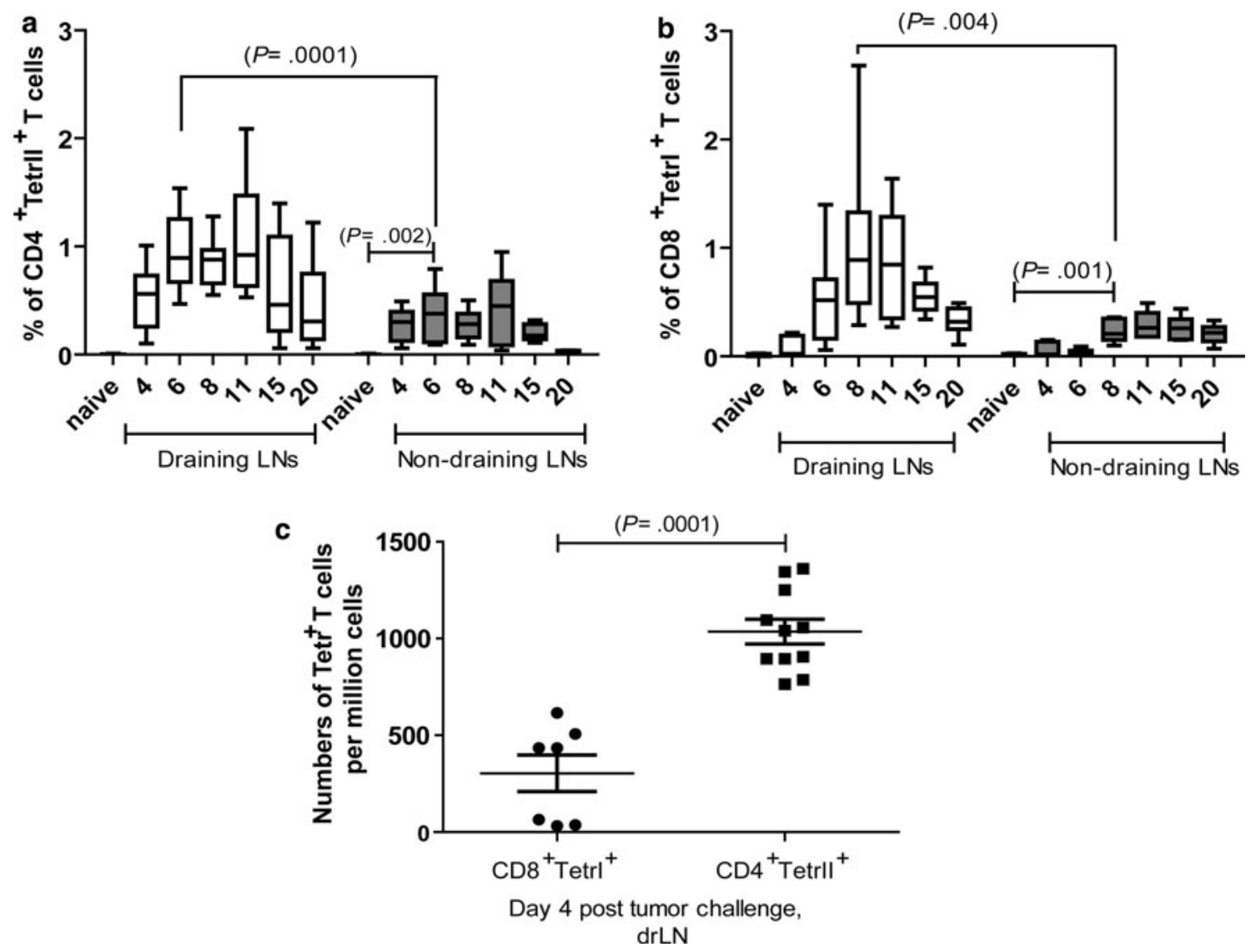

Fig. 1 Kinetics of FBL-3-specific effector $\mathrm{CD}^{+}{ }^{+}$and $\mathrm{CD}^{+}{ }^{+}$T-cell responses: B6 mice were inoculated s.c. with $1 \times 10^{7}$ FBL- 3 cells ( $n=9-12$ mice per group). Mean percentages \pm SEM of FBL-3specific $\mathrm{CD}^{+}{ }^{\text {TetII }}{ }^{+} \mathrm{T}$ cells reactive with $\mathrm{I}-\mathrm{A}^{\mathrm{b}}$ MHC class II tetramers specific for FV-Env epitope (a) and effector $\mathrm{CD}^{+} \mathrm{T}$ cells reactive with $\mathrm{MHC}$ class $\mathrm{I} H-2 \mathrm{D}^{\mathrm{b}}$ tetramers specific for the $\mathrm{FV}$ gagL CTL epitope (b) in draining (white box plots) and non-draining (grey box plots) lymph nodes. The mean percentage for each group is

expansion reached its maximum 2 days later (Fig. 1a, b). For both T-cell populations, the contraction phase began at day 15 ptc. A comparison between different lymph nodes showed that the specific $\mathrm{CD} 4^{+}$and $\mathrm{CD} 8^{+} \mathrm{T}$-cell responses were generally located in drLN as the peak expansion of $\mathrm{T}$ cells was significantly higher in drLN than in non-drLN. However, a modest increase in the percentage of specific $\mathrm{CD}^{+}$and $\mathrm{CD}^{+}{ }^{+} \mathrm{T}$ cells was also observed in non-drLN compared to lymph nodes cells from naïve animals (Fig. 1a, b). Collectively, the data demonstrate a local expansion of tumor-specific $\mathrm{T}$ cells with the $\mathrm{CD} 4^{+} \mathrm{T}$-cell response developing more rapidly than the $\mathrm{CD} 8^{+} \mathrm{T}$-cell response.

Functional activity of the tumor-specific $\mathrm{CD} 4^{+}$ and $\mathrm{CD} 8^{+} \mathrm{T}$ cells

Next, we wanted to analyze functional properties of $\mathrm{CD} 4^{+}$ and $\mathrm{CD} 8^{+} \mathrm{T}$ cells during tumor rejection. To this end, we indicated by a line. $\mathbf{c}$ Expansion of antigen-specific CD4 T cells in draining lymph nodes at day 4 ptc is shown. Each dot represents an individual mouse, and the mean numbers are indicated by a line. All tetramer-positive $\mathrm{T}$ cells expressed cell-surface activation marker CD43. Statistically significant differences between the groups are given in the figures. The experiment was repeated three times with comparable results

performed kinetic analysis of cytokine and granzyme B (GzmB) expression in $\mathrm{T}$ cells after tumor challenge. To analyze the total populations of $\mathrm{CD}^{+}$and $\mathrm{CD} 8^{+} \mathrm{T}$ cells that were activated during tumor rejection, we used the maker CD154 (CD40L) for $\mathrm{CD}^{+}{ }^{+} \mathrm{T}$ cells [21] and the activation-associated glycoform of $\mathrm{CD} 43$ for $\mathrm{CD}^{+} \mathrm{T}$ cells [22]. In order to exclude Tregs from the effector $\mathrm{CD}^{+}{ }^{+}$T-cell pool, we also stained for intracellular expression of Foxp3. In drLN nodes, the highest frequency of $\mathrm{CD}^{+}{ }^{+} \mathrm{T}$ cells producing the three cytokines IFN- $\gamma$, TNF- $\alpha$, and IL- 2 was found between day 4 and 6 ptc (Fig. 2a). At day 8 ptc, the cytokine response already started to decrease, which was earlier than the decline in tetramer II-positive $\mathrm{CD} 4^{+} \mathrm{T}$ cells (Figs. 1a, 2b). The frequency of $\mathrm{CD} 4{ }^{+} \mathrm{CD} 154^{+} \mathrm{T}$ cells producing the three cytokines was significantly higher in drLN than in nondrLN (Fig. 2b and supplementary figure S1, available on-line), which correlated with the increased percentages of tetramer-positive $\mathrm{CD} 4^{+} \mathrm{T}$ cells in drLN (Fig. 1a). 


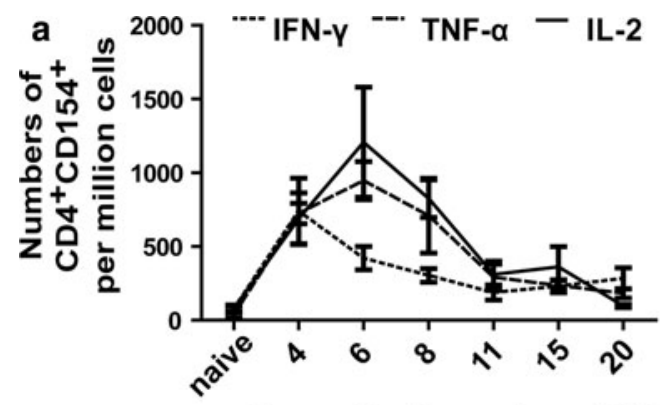

Days after tumor inoculation

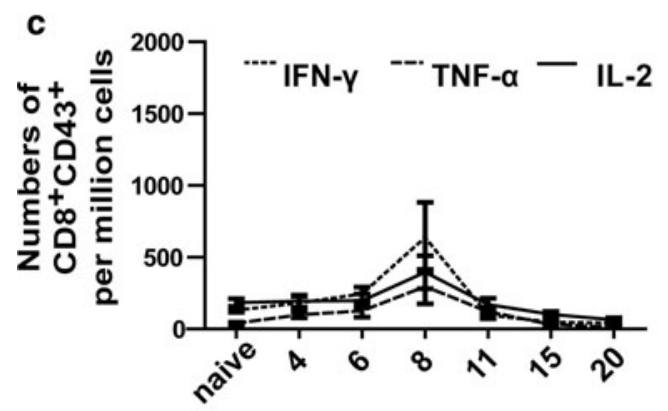

Days after tumor inoculation

Fig. 2 Cytokines and functional properties of T cells: B6 mice were inoculated s.c. with $1 \times 10^{7} \mathrm{FBL}-3$ cells. At different time points ptc, lymphocytes from lymph nodes were isolated and investigated. Kinetics of IFN- $\gamma-$, TNF- $\alpha-$, and IL-2 expressing $\mathrm{CD} 154^{+} \mathrm{CD} 4^{+}$ (a) and $\mathrm{CD}_{4} 3^{+} \mathrm{CD}^{+}$(c) $\mathrm{T}$ cells from lymph nodes are shown. b Numbers of cytokine producing $\mathrm{CD} 4{ }^{+} \mathrm{CD} 154^{+} \mathrm{T}$ cells at day $6 \mathrm{ptc}$ are depicted. Each dot represents an individual mouse and the means

The peak cytokine production by $\mathrm{CD}^{+} \mathrm{T}$ cells in $\mathrm{drLN}$ was found at day 8 ptc again showing the delay in the $\mathrm{CD} 8^{+} \mathrm{T}$-cell response compared to $\mathrm{CD} 4^{+} \mathrm{T}$ cells (Fig. 2a, c). In addition, the numbers of $\mathrm{CD} 8^{+} \mathrm{CD} 43^{+} \mathrm{T}$ cells producing cytokines were much lower than those of activated $\mathrm{CD} 4^{+} \mathrm{T}$ cells. No cytokine production by $\mathrm{CD} 8^{+}$ $\mathrm{T}$ cells was found in non-drLN during tumor rejection (data not shown). As expected, the cytotoxic molecule GzmB was also produced by $\mathrm{CD} 8^{+} \mathrm{CD} 43^{+} \mathrm{T}$ cells after tumor challenge (Fig. 2d). The peak of this functional response was found between day 8 and 11 ptc. Remarkably, tumor-induced activation of Foxp $3^{-} \mathrm{CD} 4^{+} \mathrm{T}$ cells in drLN also resulted in their differentiation into GzmBproducing cells, suggesting a potential cytotoxic role for these cells. Peak GzmB expression in $\mathrm{CD} 4{ }^{+} \mathrm{CD} 43^{+} \mathrm{T}$ cells was observed at day 6 ptc, which was again earlier as in the $\mathrm{CD} 8^{+} \mathrm{T}$-cell compartment. Thus, both $\mathrm{CD} 8^{+}$and $\mathrm{CD}^{+}{ }^{+} \mathrm{T}$-cell populations in drLN expressed pro-inflammatory cytokines and GzmB in response to tumor challenge, but the $\mathrm{CD} 4^{+} \mathrm{T}$-cell response initiated earlier and the magnitude of the response was higher than the $\mathrm{CD} 8^{+}$ T-cell response.
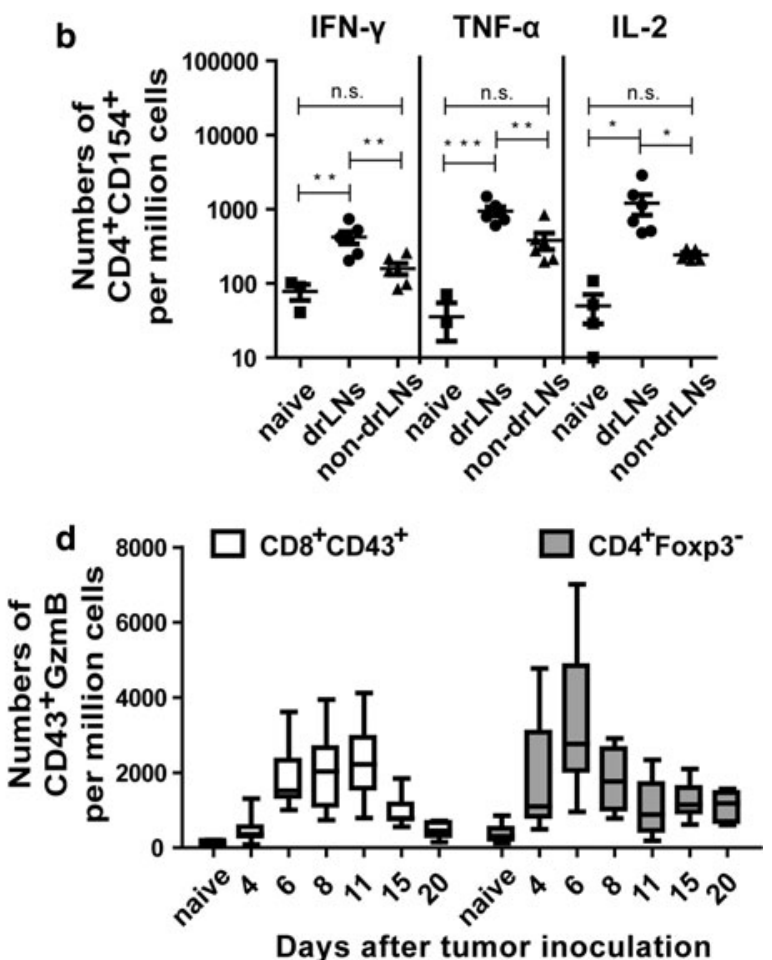

are indicated by a line. $\mathbf{d}$ Intracellular expression of GzmB. Numbers of $\mathrm{CD}^{+} \mathrm{CD}^{2} 3^{+}$(white box plots) and $\mathrm{CD} 4^{+} \mathrm{Foxp} 3^{-}$(grey box plots) $\mathrm{T}$ cells producing GzmB are shown in drLNs at different days ptc. Differences between two groups are indicated $(* P<0.05$, $* * P<0.005, * * * P<0.0005)$. All experiments were repeated three times with comparable results

Kinetics of the local Treg response during tumor rejection

Since Tregs were reported to have a suppressive role in the control of local tumor immune responses [6], we next assessed the significance of these cells in rejection of the FBL-3 tumor cells. To this end, the kinetics of Treg responses in drLN and non-drLN were compared. To distinguish between Treg and effector $\mathrm{CD} 4^{+} \mathrm{T}$-cell populations, we utilized the unique Treg marker Foxp3. Interestingly, in non-drLN, the frequency of Foxp $3^{+}$Tregs started to increase at day 4 ptc and stayed elevated until day 20 ptc in comparison with naïve animals (Fig. 3a). In contrast, in drLN Treg, frequencies decreased on day 4 ptc and remained reduced until day 15 ptc. This was a surprising finding since we knew from previous studies in the FV model that Tregs expand at the side of inflammation during a chronic virus infection [16]. One possible explanation was that these cells leave the drLN and migrate into the tumor microenvironment. To address this, tumor-infiltrating lymphocytes (TIL) were isolated and examined for Treg frequencies. From the TIL, a mean of $38 \%$ Tregs was 
Fig. 3 Regulatory $\mathrm{T}$ cells in lymph nodes: B6 mice were inoculated s.c. with $1 \times 10^{7}$ FBL-3 cells on day 0 . a Numbers of $\mathrm{CD}^{+}{ }^{+} \mathrm{Foxp}^{+}{ }^{+}$in drLNs and non-drLNs are shown. b Representative histograms display Foxp3 expression among $\mathrm{CD} 4^{+} \mathrm{T}$ cells in lymph nodes and tumor at day 6 ptc [Tumor-infiltrating lymphocytes (TILs)]. Numbers indicate percentages within the respective Foxp $3^{+}$gate. c Numbers of CD $4^{+} \mathrm{Foxp}^{+} \mathrm{T}$ cells producing GzmB in lymph nodes are shown. Each $d o t$ represents an individual mouse, and the mean numbers are indicated by a line. The experiment was repeated three times with comparable results
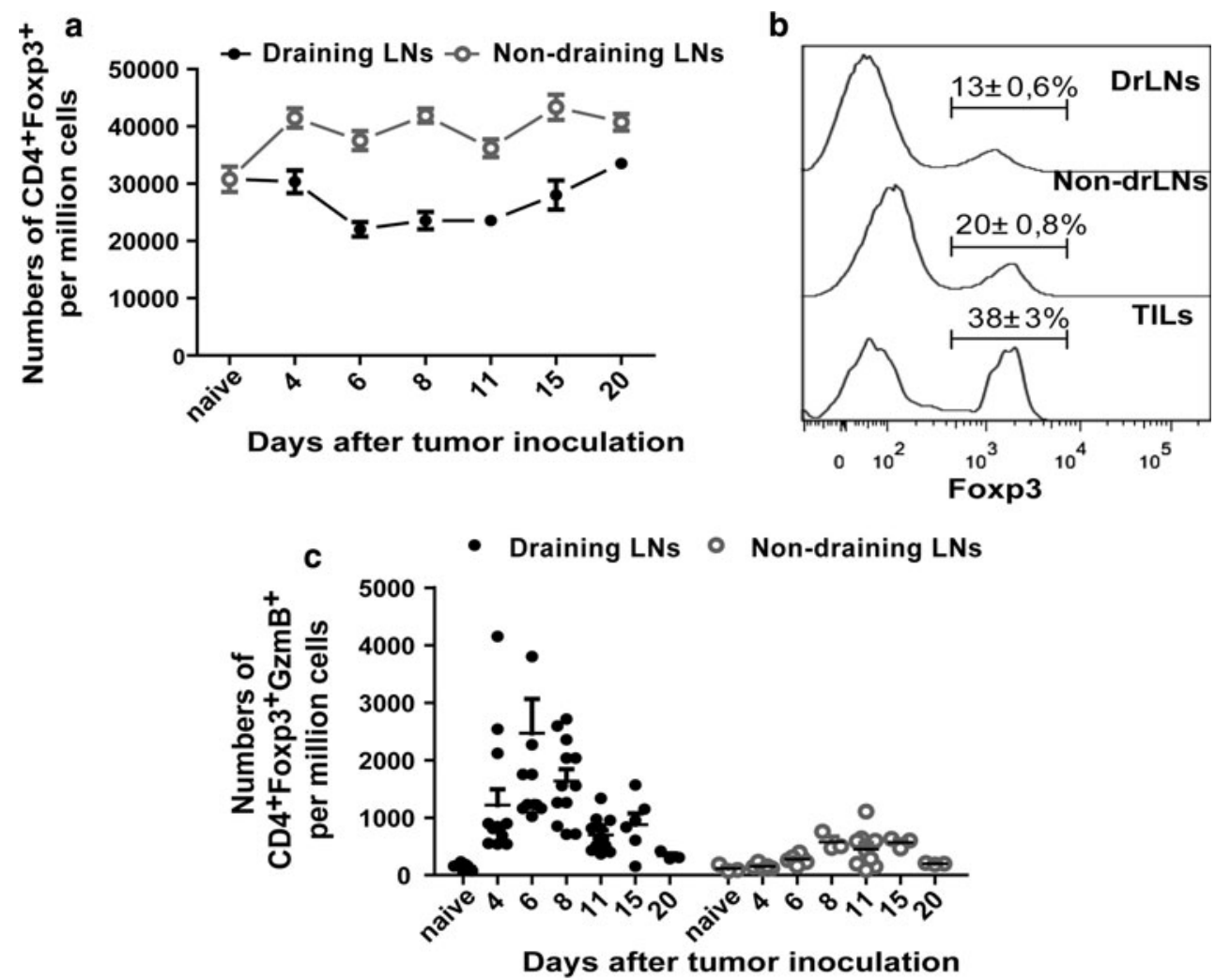

found at 6 days ptc, whereas only a mean of $13 \%$ Tregs was found in drLN, suggesting an infiltration of Tregs from the drLN into the tumor microenvironment.

One of the most potent mechanisms of Treg-mediated effector T-cell suppression is the direct killing of effector cells by the granzyme/perforin pathway $[23,24]$. Thus, we examined the production of GzmB in $\mathrm{CD} 4^{+} \mathrm{Foxp}^{+}$Tregs. In drLN, Tregs started to produce GzmB at 4-6 days ptc (Fig. 3c) and the frequency of GzmB-producing Tregs correlated with the kinetics of the overall $\mathrm{CD}^{+}{ }^{+} \mathrm{T}$-cell response (Fig. 1a). In contrast, in non-drLN, FBL-3 challenge did result in only slight expansion of GzmB-producing Tregs at day $8-15$ ptc (Fig. 3c). To analyze whether the $\mathrm{GzmB}^{+}$Tregs were natural (nTregs) or induced Tregs (iTregs), we stained for the nTreg marker Helios, a member of the Ikaros transcription factor family [25, 26]. The vast majority of the granzyme-producing Tregs expressed Helios (Supplementary figure S2, available on-line), suggesting that those cells were mostly thymic-derived nTregs.

The role of different T-cell populations in the control of tumor growth

It was previously reported that $\mathrm{CD} 8^{+} \mathrm{T}$ cells are essential in controlling FBL-3 progression, whereas $\mathrm{CD} 4^{+} \mathrm{T}$ cells did not affect the tumor growth $[11,13]$. In agreement with these previous studies, tumor regression was completely abrogated when $\mathrm{CD} 8^{+} \mathrm{T}$ cells were ablated by monoclonal antibodies (Fig. 4b). In contrast, the depletion of CD4 ${ }^{+} \mathrm{T}$ cells did only temporary increase the tumor size at 6 days ptc but did not affect the subsequent rejection of FBL-3 tumor cells (Fig. 4c). The data demonstrate that mainly $\mathrm{CD}^{+} \mathrm{T}$ cell-mediated rejection of FBL-3 tumor cells but $\mathrm{CD}^{+} \mathrm{T}$ cells had only a minor effect. However, the influence of Tregs on the different effector T-cell populations during tumor rejection is poorly understood. To investigate this influence, we studied tumor regression and T-cell functions after selective depletion of Tregs. We used transgenic DEREG mice, which express a diphtheria toxin (DT) receptor under control of the Foxp3 promoter. An injection of DT selectively depleted more than $90 \%$ of the Tregs (data not shown). No other cell population was depleted by this treatment. Interestingly, DT treatment of tumor-bearing DEREG mice did not significantly improve tumor elimination (Fig. 4d). Thus, in a tumor model in which immune surveillance and immune control are effectively mediated by tumor-specific $\mathrm{CD}^{+} \mathrm{T}$ cells, these cells do not seem to be functionally suppressed by Tregs. This is in line with our finding that depletion of Tregs did not enhance FBL-3-specific cytotoxicity of $\mathrm{CD}^{+} \mathrm{T}$ cells in an in vivo CTL assay with target cells loaded with a Friend virus immunodominant epitope peptide [9] (Fig. 4h). However, these results did not indicate whether or not tumor-specific $\mathrm{CD} 4^{+} \mathrm{T}$-cell responses were suppressed by 
Fig. 4 Influence of different cell populations on tumor formation: Effects of no depletion (injected with PBS) (a), depletion of $\mathrm{CD} 8^{+} \mathrm{T}$ cells (b), $\mathrm{CD} 4^{+} \mathrm{T}$ cells $(\mathbf{c})$, Tregs (d), $\mathrm{CD} 8^{+}$and Tregs $(\mathbf{e}), \mathrm{CD} 8^{+}, \mathrm{NK}$ cells and Tregs (f) and CD4 ${ }^{+}$ and $\mathrm{CD}^{+} \mathrm{T}$ cells $(\mathrm{g})$ are shown DEREG mice were injected s.c. with $1 \times 10^{7}$ FBL- 3 cells $\left(1 \times 10^{7}\right)$ and tumor size was measured. Mice were depleted for their $\mathrm{CD} 8^{+}, \mathrm{CD} 4^{+} \mathrm{T}$ cells, and Tregs as described in "Materials and methods." Each line represents tumor progression in an individual mouse. $\mathbf{h}$ In vivo killing activity of $\mathrm{CD}^{+} \mathrm{T}$ cells in different treatment of mice. Mean percentages show killing of cells loaded with the FV $\mathrm{D}^{\mathrm{b}}$ gagL peptide in an in vivo CTL assay (described in "Materials and methods" section) at day 6 ptc in DEREG mice treated or not treated with DT. Data were pooled from four to six independent experiments with similar results. $P$ values were determined by an unpaired $t$ test (n.s., non-significant). Dragger symbol mice were euthanized due to progressive tumor growth
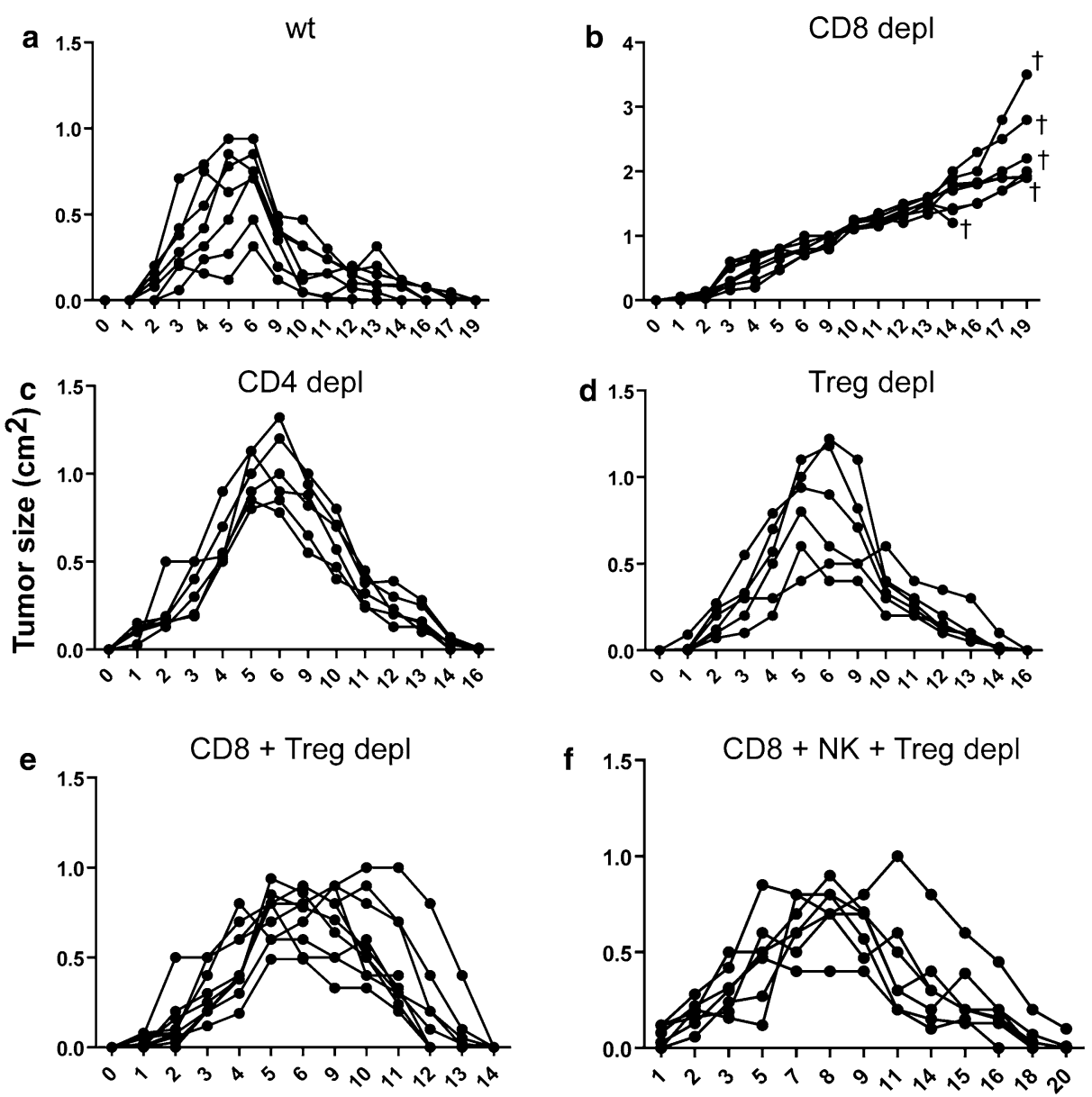

Days after tumor inoculation
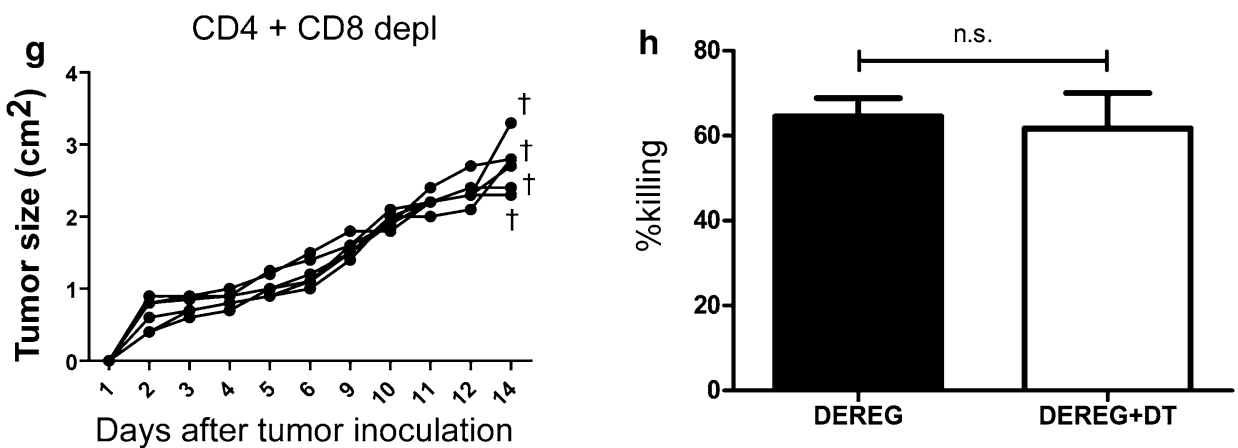

Tregs. To clarify this, we depleted Tregs and $\mathrm{CD} 8^{+} \mathrm{T}$ cells at the same time in tumor-bearing mice. Whereas $\mathrm{CD} 8^{+}$ $\mathrm{T}$-cell ablation alone resulted in progressive tumor growth (Fig. 4b), additional Treg depletion enabled the mice to again reject the tumor (Fig. 4e). The only difference to non-depleted wild-type mice was that the FBL-3 tumors increased in size for up to 4 days longer before they were rapidly rejected. To exclude a possible role of NK cells, the additional depletion of those cells in the group of mice lacking Tregs and $\mathrm{CD} 8^{+} \mathrm{T}$ cells was performed (Fig. 4f). Such mice could still reject the tumor, demonstrating that
NK cells had no effect on tumor rejection in $\mathrm{CD}^{+}{ }_{-}$ depleted mice. In order to demonstrate that tumor rejection in mice depleted for $\mathrm{CD}^{+} \mathrm{T}$ cells and Tregs (Fig. 4e) was due to effector $\mathrm{CD} 4^{+} \mathrm{T}$-cell responses, tumor growth was tested in mice lacking both $\mathrm{CD}^{+}$(including Tregs) and $\mathrm{CD} 8^{+} \mathrm{T}$ cells. In the absence of these T-cell compartments, no control of tumor growth was observed (Fig. $4 \mathrm{~g}$ ). This experiment suggests that $\mathrm{CD}^{+}{ }^{+} \mathrm{T}$ cells can mediate potent anti-tumor effects when cytotoxic $\mathrm{CD} 8^{+} \mathrm{T}$ cells are absent but that they are tightly controlled in their activity by Foxp $3^{+}$Tregs. 
The impact of Tregs on the functions of tumor-specific $\mathrm{CD}^{+}{ }^{+} \mathrm{T}$ cells

To prove that Tregs indeed control anti-tumor $\mathrm{CD} 4^{+} \mathrm{T}$-cell functions in the FBL-3 model, we analyzed numbers of tumor-specific $\mathrm{CD}^{+}{ }^{+} \mathrm{T}$ cells, their cytokine production and cytotoxic activity after Treg ablation with or without additional $\mathrm{CD}^{+}$T-cell depletion. In DT-treated DEREG mice challenged with tumor cells for 6 days, we observed a significant increase in the mean percentage of tumor-specific (tetramer $\mathrm{II}^{+}$) $\mathrm{CD}^{+} \mathrm{T}$ cells in comparison with mice that received only FBL-3 cells (Fig. 5a). Moreover, if depletion of Tregs was combined with $\mathrm{CD}^{+}$T-cell removal, the $\mathrm{CD} 4^{+} \mathrm{T}$-cell response was further significantly enhanced. $\mathrm{CD}^{+}$T-cell depletion alone did not influence the mean percentage of tumor-specific $\mathrm{CD} 4^{+} \mathrm{T}$ cells, suggesting that their expansion was mainly controlled by Tregs (Fig. 5a). Tregs did not only influence $\mathrm{CD}^{+}{ }^{+} \mathrm{T}$-cell expansion but also modified their functional properties. In DT-treated mice, significantly more $\mathrm{CD} 4^{+} \mathrm{CD} 154^{+} \mathrm{T}$ cells expressed the cytokines IFN- $\gamma, \mathrm{TNF}-\alpha$, and IL- 2 than in mice receiving only tumor cells (Fig. 5b). Dual depletion of
Fig. 5 The influence of regulatory $\mathrm{T}$ cells on tumorspecific $\mathrm{CD}^{+}{ }^{+} \mathrm{T}$-cell functions: DEREG mice were inoculated s.c. with $1 \times 10^{7}$ FBL-3 cells on day 0 . One day before tumor inoculation, some mice also received DT to deplete Foxp $3^{+}$ Tregs, and day later monoclonal antibody to deplete $\mathrm{CD} 8^{+} \mathrm{T}$ cells. At day 6 post-tumor transplantation, lymphocytes from draining lymph nodes were analyzed. a The percentages of $\mathrm{CD}^{+}{ }^{+} \mathrm{T}$ cells reactive with $\mathrm{I}-\mathrm{A}^{\mathrm{b}} \mathrm{MHC}$ class II tetramers are shown. Numbers of $\mathrm{CD} 4^{+} \mathrm{CD} 154^{+} \mathrm{T}$ cells producing cytokines (IFN- $\gamma$, TNF- $\alpha$, and IL-2) are shown (b). Numbers of activated (positive for the activation-induced isoform CD43) $\mathrm{CD}^{+}{ }^{+} \mathrm{Foxp}^{-} \mathrm{T}$ cells producing GzmB (c) and representative dot plots of GzmB and tetramer II expression (d) in different treatment of mice are shown. Differences between two groups are indicated $(* P<0.05$, $* * P<0.005)$. Results were obtained from three experiments with comparable results
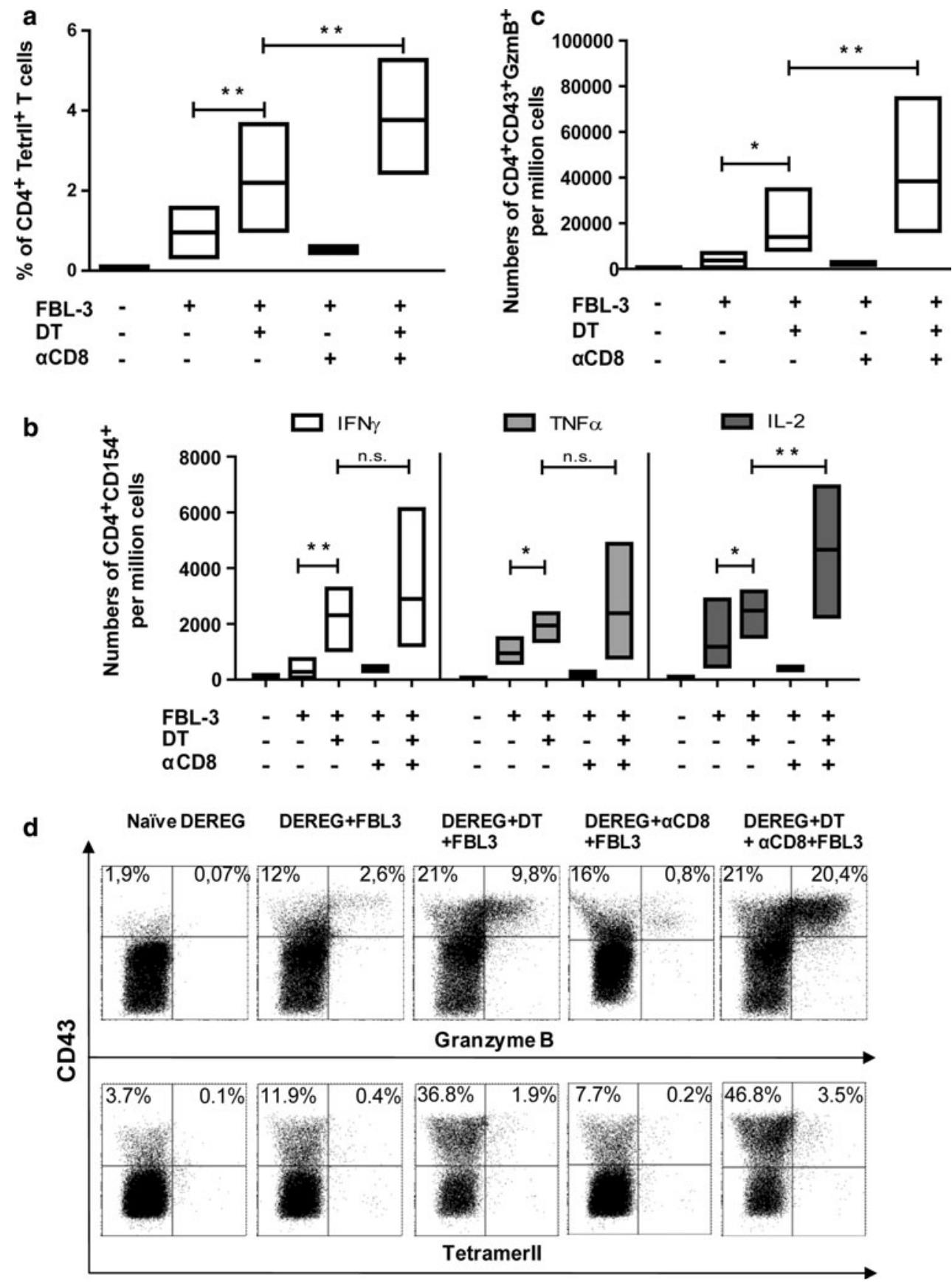
Tregs and $\mathrm{CD} 8^{+} \mathrm{T}$ cells resulted in slightly higher mean frequencies of cytokine producing $\mathrm{CD} 4^{+} \mathrm{T}$ cells than after Treg deletion alone but this difference was only significant for IL-2-producing cells (Fig. 5b). To determine possible cytotoxic effects against FBL-3 tumor cells, production of the cytolytic molecule GzmB by activated $\left(\mathrm{CD} 43^{+}\right) \mathrm{CD} 4^{+}$ $\mathrm{T}$ cells was analyzed. In mice lacking Tregs, the frequency of GzmB-positive cells was significantly higher compared to non-depleted tumor-bearing mice (Fig. 5c, d). Additional ablation of $\mathrm{CD}^{+} \mathrm{T}$ cells together with the Tregs resulted in a significant rise in the mean frequencies of $\mathrm{GzmB}^{+} \mathrm{CD} 4^{+}$ $\mathrm{T}$ cells in comparison with mice only depleted for Tregs (Fig. 5c). Again, $\mathrm{CD}^{+}$T-cell depletion alone did not influence the functional $\mathrm{CD} 4^{+} \mathrm{T}$-cell response during tumor rejection (Fig. 5c, d).

The cytotoxic potential of tumor-specific $\mathrm{CD} 4^{+} \mathrm{T}$ cells in vivo

To analyze whether the increased expression of GzmB correlated with improved tumor-specific lysis of target cells after Treg depletion, we performed a series of in vivo killing experiments. The in vivo killing activity was quantified in the drLN of each mouse during tumor rejection. In non-depleted animals, $\mathrm{CD}^{+} \mathrm{T}$ cells showed a modest in vivo killing activity not exceeding a mean of $13 \%$ target cell lysis (Fig. 6a). Surprisingly, depletion of Tregs alone did not significantly improve the lysis of target cells. In contrast, simultaneous ablation of $\mathrm{CD}^{+} \mathrm{T}$ cells and Treg significantly enhances the killing of peptide-loaded cells (Fig. 6a, b), which correlated with the high frequency of GzmB-producing cells in this group of mice (Fig. 5c, d). Notably, in this group, tumor growth was completely rejected even in the absence of $\mathrm{CD} 8^{+} \mathrm{T}$ cells (Fig. 4e). To demonstrate that cytotoxic $\mathrm{CD}^{+}{ }^{+} \mathrm{T}$ cells mediated the target cell killing in the group of $\mathrm{CD}^{+} \mathrm{T}$ cell plus Treg depleted mice, we additionally depleted the effector $\mathrm{CD}^{+}{ }^{+} \mathrm{T}$ cells. This completely abrogated the MHC II-restricted killing activity (Fig. 6a). Collectively, these data suggest that $\mathrm{CD} 4^{+} \mathrm{T}$ cells can gain cytotoxic activity against tumor cells when $\mathrm{CD} 8^{+} \mathrm{T}$ cells are not active but this activity is tightly controlled by Tregs during tumor rejection.

Upregulation of MHC class II molecule on FBL-3 cells in vivo

The level of MHC II expression directly influences T-lymphocyte activation and recognition of target cells by $\mathrm{CD} 4^{+} \mathrm{T}$ cells. It has been published previously that $\mathrm{CD} 4^{+}$ $\mathrm{T}$ cells cannot directly recognize FBL-3, since they only express MHC class I but no MHC class II molecules [27]. However, our in vivo experiments strongly suggest a cytotoxic activity of $\mathrm{CD} 4^{+} \mathrm{T}$ cells against FBL-3 tumors. Therefore, the MHC class II expression of FBL-3 tumor cells extracted directly from tumor-bearing mice was analyzed. As expected, no MHC class II molecules were found on FBL-3 cells from cell culture (Supplementary figure S3a, available on-line). To study MHC class II expression in vivo and to distinguish the FBL-3 from tumor-infiltrating cells, CD45.1 transgenic mice were used. In these mice, all leukocytes express the CD45.1 alloantigen and therefore can be excluded by the surface staining. Interestingly, after being in the host environment, the phenotype of the FBL-3 cells had partially changed. A proportion of $14 \%$ of the inoculated MHC II-deficient
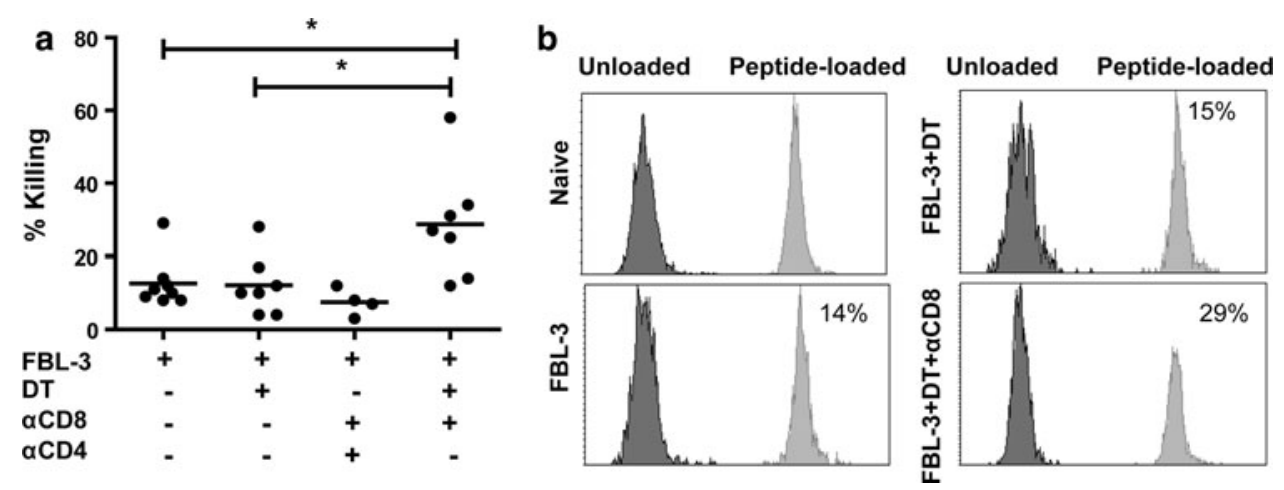

Fig. 6 In vivo killing activity of $\mathrm{CD}^{+} \mathrm{T}$ cells after different treatment of mice: Mean percentages of killing (a) and representative histograms (b) of in vivo CTL assay are depicted. Tumor-bearing mice were depleted for their Tregs alone or additionally for their $\mathrm{CD}^{+} \mathrm{T}$ cells. Target cells from donor CD45.1 mice $\left(\mathrm{CFSE}^{+}\right.$and $\mathrm{CFSE}^{-}$) were co-transferred i.v. in the same amount into tumorbearing mice. $\mathrm{CFSE}^{+}$cells were loaded with the class II-restricted peptide recognized by $\mathrm{CD} 4^{+} \mathrm{T}$ cells, whereas $\mathrm{CFSE}^{-}$cells were used as a control population $2 \mathrm{~h}$ later, lymphocytes were isolated from the draining lymph nodes and analyzed by flow cytometry to determine the percentage of remaining target cells that are either $\mathrm{CFSE}^{+}$or $\mathrm{CFSE}^{-}$. Each dot represents an individual mouse, and the mean percentages are indicated by a line. Differences between two groups are indicated $(* P<0.05)$. All experiments were repeated two times with comparable results 
FBL-3 cells became I- $\mathrm{A}^{\mathrm{b}}$-positive after 4 days ptc in CD45.1 mice (Supplementary figure S3b, available on-line). These MHC-II-expressing FBL-3 cells could be a possible target for cytotoxic $\mathrm{CD} 4^{+} \mathrm{T}$ cells and might explain part of the $\mathrm{CD} 4^{+}$ T-cell-mediated FBL-3 tumor rejection (Fig. 4e).

The role of macrophages in FBL-3 tumor growth

It is well known that macrophages can contribute to tumor rejection. We therefore focused our study on the role of these cells in FBL-3 tumor growth. Since tumor-bearing mice depleted for $\mathrm{CD} 8^{+} \mathrm{T}$ cells and Tregs showed complete tumor rejection, we analyzed in this group for $\mathrm{CD} 11 \mathrm{~b}^{+} \mathrm{F} 4 / 80^{+}$macrophage activation (expression of CD86 [28]) at day 6 ptc in lymph nodes in comparison with non-depleted and naïve animal. Significant expansion of $\mathrm{CD} 11 \mathrm{~b}^{+} \mathrm{F} 4 / 80^{+}$macrophages from drLNs but not in nondrLNs was observed (Fig. 7a). Depletion of $\mathrm{CD}^{+} \mathrm{T}$ cells and Tregs also promoted the upregulation of the costimulatory molecule CD86, which indicated macrophage activation (Fig. 7b). Interestingly, activated macrophages did not produce granzyme B (data not shown). However,
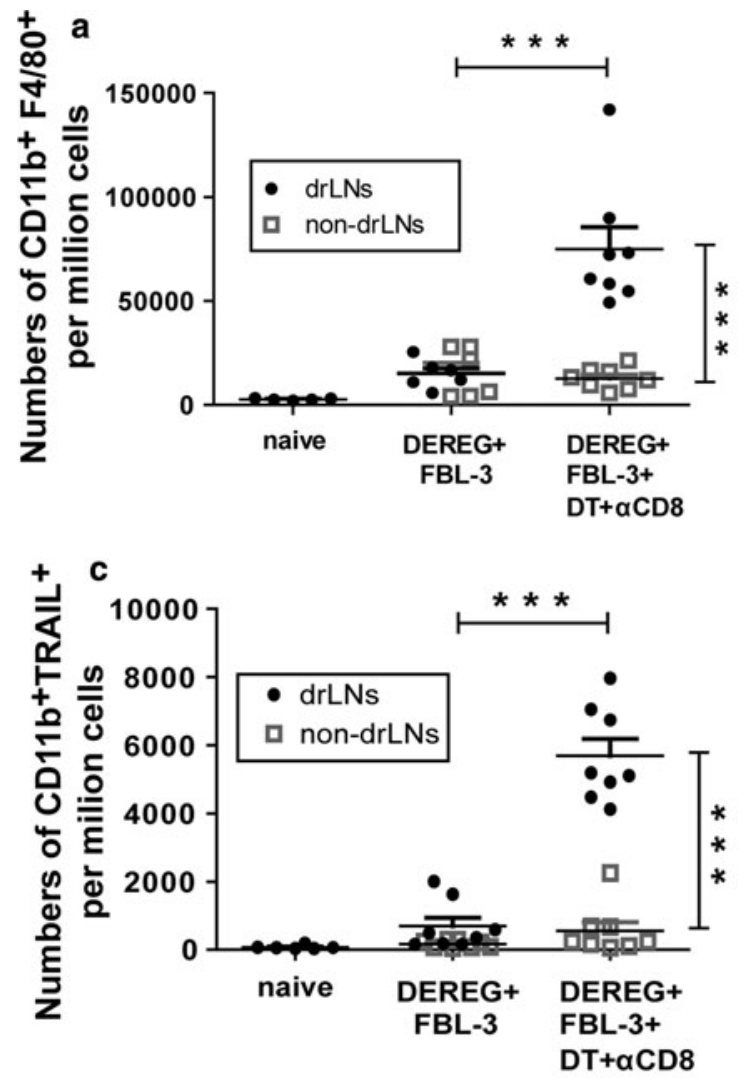

d



Fig. 7 The role of macrophages in FBL-3 tumor growth: DEREG mice were inoculated s.c. with $1 \times 10^{7}$ FBL- 3 cells on day 0 . One day before tumor inoculation, some mice also received DT to deplete Foxp $^{+}$Tregs and day later monoclonal antibody to deplete $\mathrm{CD} 8^{+} \mathrm{T}$ cells. At day 6 post-tumor transplantation, leukocytes from drLNs and non-drLNs were analyzed. Numbers of $\mathrm{CD} 11 \mathrm{~b}^{+} \mathrm{F} 4 / 80^{+}$cells are

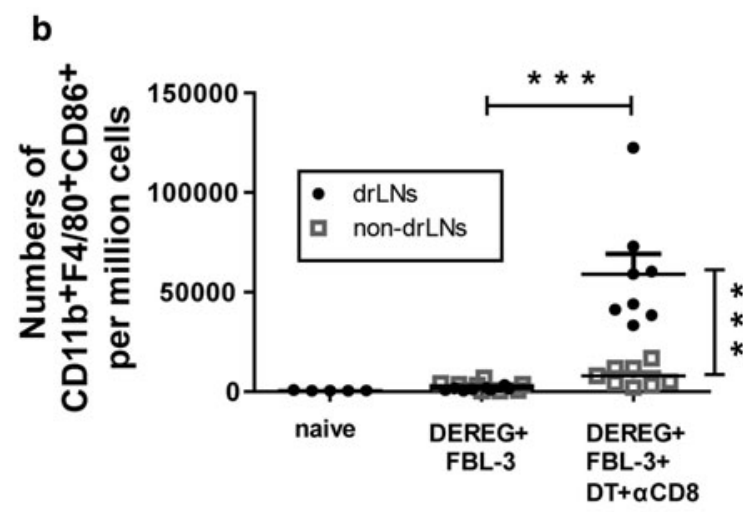

3+DT+aCD8

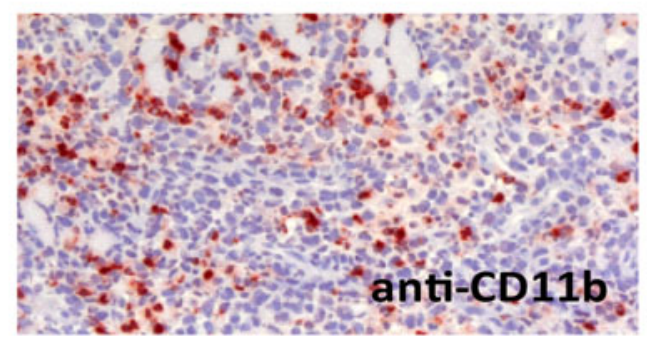

shown (a). Numbers of $\mathrm{CD} 11 \mathrm{~b}^{+} \mathrm{F} 4 / 80^{+} \mathrm{CD} 86^{+}$(b) and

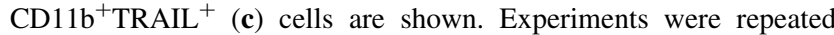
twice with similar results. Differences between two groups are indicated $(* * * P<0.0005)$. The infiltration of $\mathrm{CD}^{+} \mathrm{T}$ cells and $\mathrm{CD}_{11 \mathrm{~b}^{+}}$macrophages into the tumor is shown by immunohistology (d) (magnification $\times 200$ ) 
significantly increased expression of the TNF-related apoptosis-inducing ligand (TRAIL) that can induce tumor cells apoptosis [29] was detected on macrophages from drLNs of mice depleted for $\mathrm{CD}^{+} \mathrm{T}$ cells and Tregs compared to non-depleted controls (Fig. 7c). These data were in line with the immunohistochemistry of tumors from the dual depleted group that showed infiltration of $\mathrm{CD}_{11} \mathrm{~b}^{+}$macrophages in the tumor mass in addition to $\mathrm{CD}^{+}{ }^{+}$T-cell infiltration (Fig. 7d).

\section{Discussion}

The $\mathrm{CD}^{+}{ }^{+}$-helper $\mathrm{T}$-cell response represents a critical part of a functional immune system and is well characterized in many tumors but its effector role in the control of virusinduced tumors remains unclear. In the current research, we have used a highly immunogenic FV-induced tumor cell line of C57BL/6 mouse origin, namely FBL-3 cells, as a model to study the mechanisms of immunological control and escape during tumor formation. Our studies show that when $\mathrm{CD}^{+} \mathrm{T}$ cells were unable to control FBL-3 tumor development, cytotoxic effector $\mathrm{CD}^{+}{ }^{+} \mathrm{T}$ cells were able to take over and eliminate the tumor. However, direct antitumor effects of $\mathrm{CD}^{+}{ }^{+} \mathrm{T}$ cells were strictly regulated by Tregs, which thereby contributed toward tumor progression.

Here, we compared the kinetics of the $\mathrm{CD}^{+}{ }^{+} \mathrm{T}$-cell response to $\mathrm{FBL}-3$ tumor antigen in drLN with the $\mathrm{CD}^{+}$ $\mathrm{T}$-cell response and found a more rapid development of the $\mathrm{CD}^{+}{ }^{+}$T-cell response after FBL-3 injection. Peak expansion of tumor-specific $\mathrm{CD}^{+}{ }^{+} \mathrm{T}$ cells was observed 2 days later as the $\mathrm{CD}^{+} \mathrm{T}$ cell. In contrast, in a virus infection model with FV peak tetramer-positive CD8 T-cell, responses were far greater in magnitude $[18,30]$ than peak tetramer-positive CD4 T-cell responses [17]. In previous studies using the Moloney murine sarcoma and leukemia virus complex (MoMSV), which share the immunodominant $\mathrm{CD}^{+}$and $\mathrm{CD}^{+}{ }^{+}$T-cell epitopes with $\mathrm{FV}$, the burst size of the virus-specific $\mathrm{CD} 8^{+} \mathrm{T}$-cell response was considerably larger than that of virus-specific $\mathrm{CD}^{+} \mathrm{T}$ cells in drLNs [20].

Immune escape of tumors has been studied in many models and has in part been attributed to active suppression mediated by $\mathrm{CD}^{+}{ }^{+}$Foxp $3^{+}$Tregs [31]. The drLN is the site of the critical decision between immune activation and tolerance and has a major influence on host immunity. The current study shows that the Tregs from the drLNs appear to migrate into the tumor and influence the local microenvironment. The influence of Treg localization (sentinel lymph nodes and tumor) on cancer progression is still disputed [32-35]. The assessment of circulating Tregs or Tregs infiltrating the tumor itself has been used as a prognostic indicator in human cancers but conflicting results were obtained in different tumor diseases. Curiel et al. [32] reported that the presence of high numbers of $\mathrm{CD} 4{ }^{+} \mathrm{CD} 25^{+} \mathrm{Foxp}^{+}$cells in malignant ascites of ovarian carcinoma correlated with tumor staging and reduced survival. In colorectal cancer patients, it was demonstrated that Tregs in drLNs correlated better with disease progression and tumor stage [33]. Another observation in breast carcinoma indicated that Treg localized within lymphoid aggregates, but not in the tumor area, had a negative impact on patients' survival [34]. The finding agrees with animal models of colon cancer [36] and goes in line with our study. This suggests that Tregs in the drLNs can inhibit the development of effector cells such as cytotoxic $\mathrm{CD}^{+}{ }^{+}$and $\mathrm{CD}^{+} \mathrm{T}$ cells, whereas Tregs in the tumor itself may have dual functions of controlling tumorpromoting inflammation on one hand but suppressing local effector T-cell responses on the other [37]. Thus, in studies aimed at analyzing the impact of Tregs on tumor progression, it is critical to take the localization of Foxp3 ${ }^{+}$ Treg into account.

Although the perforin/granzyme pathway was previously known to be utilized by $\mathrm{CD}^{+} \mathrm{T}$ cells and NK cells to lyse target cells, recent studies have suggested that Tregs may also use perforin/granzyme-mediated cytotoxicity as a mechanism to kill conventional $\mathrm{T}$ cells [23, 24]. In our study, we showed that after FBL-3 challenge, Tregs in the drLNs started to produce GzmB. Moreover, the frequency of GzmB-producing Tregs correlated with the kinetics of the effector $\mathrm{CD}^{+}$T-cell response. This observation and data from Treg depletion experiments strongly suggest that GzmB-producing Tregs suppress anti-tumor $\mathrm{CD}^{+}{ }^{+} \mathrm{T}$-cell responses. Grossman et al. [38] showed that activated human Tregs expressed granzyme A and/or B and could kill activated $\mathrm{CD}^{+}{ }^{+}$and $\mathrm{CD}^{+}{ }^{+} \mathrm{T}$ cells. This Treg-mediated killing was perforin-dependent [38]. Similarly, Gondek et al. [23] reported that murine Tregs stimulated with antiCD3 mAb expressed GzmB and could suppress conventional $\mathrm{CD}^{+}{ }^{+} \mathrm{T}$ cells in a cell contact and GzmB-dependent manner. Using a system of tumor inoculation and adoptive transfer of Tregs, it was shown that GzmB was highly induced in tumor-associated Tregs by local factors in the tumor microenvironment [39]. Thus, cytotoxic activity of Tregs might be a general mechanism of Treg-mediated suppression in tumor development. Interestingly, this is different to Treg activity in chronic infectious diseases in which most activated Tregs do not express granzymes [16].

It was previously reported that $\mathrm{CD}^{+} \mathrm{T}$ cells are essential in controlling FBL-3 progression [11, 12]. After administration of anti-CD8 $\mathrm{mAb}$, rejection of local tumors induced by FBL-3 challenge was blocked and mice died from systemic lymph node metastases [12]. In agreement with these previous studies, we showed that the absence of $\mathrm{CD}^{+}{ }^{+} \mathrm{T}$ cells during FBL-3 formation did not significantly 
influence the tumor growth [13]. Although we found a very potent and rapid $\mathrm{CD}^{+}{ }^{+} \mathrm{T}$-cell response (production of cytokines and cytotoxins), these cells had only a minor effect on FBL-3 tumor rejection. Most likely, a direct antitumor effect of $\mathrm{CD} 4^{+} \mathrm{T}$ cells is not required in a system in which the cytotoxic function of $\mathrm{CD} 8^{+} \mathrm{T}$ cells is sufficient to mediate the successful rejection of the tumor. However, effector $\mathrm{CD}^{+}{ }^{+} \mathrm{T}$ cells could replace cytotoxic $\mathrm{CD} 8^{+} \mathrm{T}$ cells but they were under tight regulation by Tregs. While $\mathrm{CD}^{+}{ }^{+}$T-cell ablation alone resulted in uncontrolled tumor growth [12, 13], additional Treg depletion enabled the $\mathrm{CD}^{+}{ }^{+} \mathrm{T}$ cells to reject the tumor. Control experiments showed that this anti-tumor effect was exclusively mediated by effector $\mathrm{CD}^{+}{ }^{+} \mathrm{T}$ cells (Fig. $4 \mathrm{~g}$ ). To define the suppressive effects of Tregs on conventional $\mathrm{T}$ cells, one has to take their functions on CD4 and CD8 populations into account. Our current study shows that Treg depletion had no biological effect on $\mathrm{CD} 8^{+}$T-cell-mediated tumor rejection. Although $\mathrm{CD}^{+}$T-cell functions were augmented after Treg depletion (data not shown), this did not result in faster tumor rejection, most likely because the antitumor CTL were very efficient even under the suppressing influence of Tregs. In contrast, in FV infection, the functional suppression by Tregs mainly targeted $\mathrm{CD} 8^{+} \mathrm{T}$ cells [40], resulting in the development of functional exhausted $\mathrm{CD}^{+} \mathrm{T}$ cells and in high FV loads in lymphatic organs [16]. Earlier Iwashiro et al. [11] demonstrated that mice persistently infected with FV have approximately twice the normal percentage of splenic $\mathrm{CD} 4{ }^{+} \mathrm{CD} 25^{+}$Tregs and lose their ability to reject the implantation of FBL-3 cells. In a mouse model of spontaneous mammary carcinoma, the depletion of Tregs resulted in $\mathrm{CD}^{+}{ }^{+} \mathrm{T}$-cell activation and subsequent development of efficient $\mathrm{CD} 8^{+}$ T-cell activity [41]. In two other models of antitumor immunity, it was proposed that Tregs diminished $\mathrm{CD}^{+}$ T-cell function by consuming IL-2 [42] or by preventing cytotoxic granule release [43]. In a model of autoimmunity, other authors proposed that DCs were central to Treg inhibition in vivo and attenuated priming of CD4-helper cells [44]. Hence, it seems to depend on the environment and the type of immunity whether Tregs preferentially regulate $\mathrm{CD} 4^{+}$or $\mathrm{CD} 8^{+} \mathrm{T}$-cell populations. In addition, the specificity of Treg depletion might also influence the results in certain experiments. The use of non-specific Treg targeting agents such as CD25-depleting antibodies, which in addition to $\mathrm{CD} 25^{+}$Tregs also deplete recently activated $\mathrm{CD} 25^{+}$effector $\mathrm{T}$ cells, can complicate the interpretation of the data. In our study, we used transgenic DEREG mice, which express a diphtheria toxin receptor under the control of the Foxp3 promoter, allowing highly selective depletion of Foxp $3^{+}$Tregs even during ongoing immune responses [45]. Our finding that Tregs preferentially influence the anti-tumor $\mathrm{CD} 4{ }^{+} \mathrm{T}$-cell immune response revealed several aspects that had not been reported previously. The CD4 ${ }^{+} \mathrm{T}$ cells residing in the drLNs of mice depleted of Tregs and $\mathrm{CD}^{+} \mathrm{T}$ cells showed major changes to those of nondepleted mice. We demonstrated that in vivo depletion of Tregs and $\mathrm{CD}^{+} \mathrm{T}$ cells in FBL-3-bearing DEREG transgenic mice augments GzmB production by $\mathrm{CD} 4^{+} \mathrm{T}$ cells and increases $\mathrm{FV}$-specific $\mathrm{CD} 4^{+}{ }^{+} \mathrm{T}$-cell effector and cytotoxic responses leading to the complete tumor regression. Therefore, the Foxp $3^{+}$Tregs control the proliferation and function of effector $\mathrm{CD} 4^{+} \mathrm{T}$ cells and prevent the induction of efficient $\mathrm{CD}^{+} \mathrm{T}$ cells with cytotoxic potential. It was previously shown that in the murine mammary carcinoma model, deletion of Tregs resulted in increasing numbers of IFN- $\gamma$ and IL-2-producing $\mathrm{CD} 4^{+} \mathrm{T}$ cells at tumor sites [41]. However, the $\mathrm{CD} 4^{+} \mathrm{T}$ cells alone, even in the absence of Treg suppression, were not sufficient to abrogate tumor progression [41] but the Treg removal was performed by using anti-CD25 antibodies and depletion of Tregs was incomplete [41]. Another group has also used DEREG mice for selective depletion of Tregs [46]. However, the regression of the melanoma growth, which was induced by depletion of Foxp $3^{+}$Tregs, was critically dependent on the presence of $\mathrm{CD}^{+} \mathrm{T}$ cells in this model and additional elimination of those cells resulted in ongoing tumor progression [46].

We show here that the immune system may still be capable of controlling tumor development in the absence of the main cytotoxic population $\left(\mathrm{CD} 8^{+} \mathrm{T}\right.$ cells). However, underlying mechanisms that influence the activity of effector $\mathrm{CD} 4^{+} \mathrm{T}$ cells in the absence of $\mathrm{CD} 8^{+} \mathrm{T}$ cells are poorly defined. $\mathrm{CD} 8^{+} \mathrm{Foxp}^{+} \mathrm{T}$ cells were reported to mediate immunosuppression in cancer patients [47]. Depletion of these $\mathrm{CD}^{+} \mathrm{Foxp}^{+}$Tregs in addition to $\mathrm{CD}^{+}{ }^{+} \mathrm{Foxp}^{+}{ }^{+}$Tregs might allow for antitumor cytotoxic function of $\mathrm{CD}^{+}{ }^{+} \mathrm{T}$ cells and tumor rejection. Moreover, some of the molecules that are produced by $\mathrm{CD} 8^{+} \mathrm{T}$ cells, such as granzymes, may have immunomodulatory effects on other $\mathrm{T}$ cells [48].

To demonstrate that the increased expression of GzmB by effector $\mathrm{CD}^{+} \mathrm{T}$ cells resulted in antigen-specific cytotoxicity in vivo after depletion of Foxp $3^{+}$Tregs, we performed an in vivo CTL assay. $\mathrm{CD}^{+} \mathrm{T}$ cells showed potent killing activity of peptide-loaded targets in the drLN of FBL-3-bearing mice. The acquisition of cytotoxic activity by tumor-reactive $\mathrm{CD} 4^{+} \mathrm{T}$ cells is particularly striking since it only emerged when the suppressive function of Tregs was blocked. From previous work, we knew that $\mathrm{CD} 4^{+} \mathrm{T}$ cells can help rejection of tumors through indirect effects on NK cells [49] and tumor-infiltrating macrophages $[1,50,51]$ and Tregs can negatively influence this help by inhibiting IFN- $\gamma$ synthesis [52]. Cytotoxic $\mathrm{CD}^{+}$targeting viral antigens [53-55] and alloantigens [56-58] have been described previously, but in these 
models, the influence of Tregs on effector $\mathrm{CD} 4^{+}$T-cell activity was not investigated but the tumor or the pathogen was eliminated by adoptive transfer of effector $\mathrm{CD} 4^{+} \mathrm{T}$ cells [57, 59]. Quezada et al. [57] showed effector CD4 ${ }^{+}$ T-cell-dependent tumor rejection when radiotherapy and adoptive transfer of tumor-reactive $\mathrm{CD}^{+}{ }^{+} \mathrm{T}$ cells were combined with the blockade of the CTLA-4 molecule that is expressed on Tregs [60, 61], suggesting that Tregs influenced cytotoxic $\mathrm{CD} 4^{+} \mathrm{T}$ cells in this model as well.

As published previously, $\mathrm{CD} 4^{+} \mathrm{T}$ cells cannot directly recognize FBL-3, since they only express MHC class I but not MHC class II molecules in vitro [27] (Supplementary figure S3a,). However, our in vivo experiments strongly suggest cytotoxic activity of $\mathrm{CD}^{+}{ }^{+} \mathrm{T}$ cells against FBL-3 tumor cells. In the current study (Supplementary figure $\mathrm{S} 3 \mathrm{~b}$ ), we showed that after being in the host environment, a proportion of the inoculated MHC II-deficient FBL-3 cells became $\mathrm{I}-\mathrm{A}^{\mathrm{b}}$-positive. In addition, $\mathrm{CD} 4^{+} \mathrm{T}$ cells can support killing of tumor cells by indirect mechanisms including recruitment of antigen-presenting cells [27, 62] or killing stroma cells [63] that support tumor growth. A combination of such mechanisms can elucidate the antigen-specific elimination of FBL- 3 tumors by cytotoxic $\mathrm{CD} 4^{+} \mathrm{T}$ cells.

It is well established that solid tumors are often infiltrated by macrophages. As previously published, these cells play an important role in the FBL-3 tumor model [27]. In our study, we illustrate significant expansion of activated $\mathrm{CD} 11 \mathrm{~b}^{+} \mathrm{F} 4 / 80^{+}$macrophages that produce TRAIL in drLNs after depletion of Tregs and $\mathrm{CD}^{+} \mathrm{T}$ cells. Moreover, infiltration of $\mathrm{CD}_{1} 1 \mathrm{~b}^{+}$cells into the tumor mass was shown, which suggests an antitumor effector function of macrophages. Activated macrophages have been reported to secrete a number of molecules with tumorocidal effects, like nitric oxide and reactive oxygen intermediates, and thus can partly mediate antitumor activity [64]. In addition, antitumor function of macrophages can be stimulated by IFN- $\gamma$-producing $\mathrm{CD}^{+}{ }^{+} \mathrm{T}$ cells. However, macrophages alone could not control FBL-3 cell growth in the absence of $\mathrm{CD}^{+}{ }^{+}$and $\mathrm{CD}^{+}{ }^{+} \mathrm{T}$ cells (Fig. $4 \mathrm{~g}$ ). Thus, we believe that tumor-specific $\mathrm{CD}^{+}{ }^{\mathrm{T}}$ cells can facilitate direct anti-tumor activity, which can be supported by $\mathrm{TRAIL}^{+}$macrophages inducing the classical macrophage activation pathway that contributes to inhibition of tumor cell growth [65].

The direct antitumor role of $\mathrm{CD}^{+}{ }^{+} \mathrm{T}$ cells has been controversially discussed since most tumors do not express MHC II and thus cannot be directly recognized by $\mathrm{CD} 4^{+} \mathrm{T}$ cells. Nonetheless, there are a number of HLA-DRexpressing tumors in patients [66]. Moreover, HLA-DR expression is associated with better prognosis in colorectal cancers [67]. The ability of MHC II-negative tumors to start to express class II molecules in the tumor microenvironment can be applied in cancer immunotherapy. Recent investigations in melanoma patients showed effectiveness of adoptive $\mathrm{CD} 4^{+}$T-cell therapy [68]. Thus, analyzing for HLA-DR expression of the primary tumor and metastasis and subsequent adoptive $\mathrm{CD} 4^{+}$T-cell transfer might be a promising approach for future immunotherapy.

Cytotoxic $\mathrm{CD} 4^{+}$T-cell activity against MHC II-negative tumors can also be used in cancer immunotherapy. Genetic modification of cytotoxic $\mathrm{T}$ cells with chimeric antigen receptors (CARs) specific for tumor antigen allows MHC-independent antigen recognition that nonetheless retains the T-cell effector mechanisms that are needed to eliminate tumor cells [69].

In conclusion, our studies have established a critical role for cytotoxic $\mathrm{CD}^{+}{ }^{+} \mathrm{T}$ cells in the context of oncoviral diseases. We propose that effector $\mathrm{CD} 4^{+} \mathrm{T}$ cells, which are largely regulated by Foxp $3^{+}$Tregs during tumor formation, are capable of maintaining immune control against FBL-3 tumor via direct killing and can functionally replace $\mathrm{CD} 8^{+}$ $\mathrm{T}$ cells. We suggest that cytotoxic $\mathrm{CD} 4^{+} \mathrm{T}$-cell immune responses may be induced therapeutically to enhance resistance against oncovirus-associated tumors.

Conflict of interest The authors declare that they have no conflict of interest.

Open Access This article is distributed under the terms of the Creative Commons Attribution License which permits any use, distribution, and reproduction in any medium, provided the original author(s) and the source are credited.

\section{References}

1. Hung K, Hayashi R, Lafond-Walker A, Lowenstein C, Pardoll D, Levitsky H (1998) The central role of CD4(+) T cells in the antitumor immune response. J Exp Med 188(12):2357-2368

2. Lauritzsen GF, Weiss S, Dembic Z, Bogen B (1994) Naive idiotype-specific CD4+ T cells and immunosurveillance of B-cell tumors. Proc Natl Acad Sci USA 91(12):5700-5704

3. Bagot M, Echchakir H, Mami-Chouaib F, Delfau-Larue MH, Charue D, Bernheim A, Chouaib S, Boumsell L, Bensussan A (1998) Isolation of tumor-specific cytotoxic CD4+ and CD4+ CD8dim+ T-cell clones infiltrating a cutaneous T-cell lymphoma. Blood 91(11):4331-4341

4. Hombach A, Kohler H, Rappl G, Abken H (2006) Human CD4+ $\mathrm{T}$ cells lyse target cells via granzyme/perforin upon circumvention of MHC class II restriction by an antibody-like immunoreceptor. J Immunol 177(8):5668-5675

5. Homma S, Komita H, Sagawa Y, Ohno T, Toda G (2005) Antitumour activity mediated by CD4+ cytotoxic T lymphocytes against MHC class II-negative mouse hepatocellular carcinoma induced by dendritic cell vaccine and interleukin-12. Immunology 115(4):451-461. doi:10.1111/j.1365-2567.2005.02179.x

6. Viguier M, Lemaitre F, Verola O, Cho MS, Gorochov G, Dubertret L, Bachelez H, Kourilsky P, Ferradini L (2004) Foxp3 expressing CD4+ CD25(high) regulatory $\mathrm{T}$ cells are overrepresented in human metastatic melanoma lymph nodes and inhibit the function of infiltrating T cells. J Immunol 173(2):1444-1453 
7. Sakaguchi S (2004) Naturally arising CD4+ regulatory t cells for immunologic self-tolerance and negative control of immune responses. Annu Rev Immunol 22:531-562. doi:10.1146/annurev. immunol.21.120601.141122

8. Glynn JP, McCoy JL, Fefer A (1968) Cross-resistance to the transplantation of syngeneic Friend, Moloney, and Rauscher virus-induced tumors. Cancer Res 28(3):434-439

9. Chen W, Qin H, Chesebro B, Cheever MA (1996) Identification of a gag-encoded cytotoxic T-lymphocyte epitope from FBL-3 leukemia shared by Friend, Moloney, and Rauscher murine leukemia virus-induced tumors. J Virol 70(11):7773-7782

10. Iwashiro M, Kondo T, Shimizu T, Yamagishi H, Takahashi K, Matsubayashi Y, Masuda T, Otaka A, Fujii N, Ishimoto A et al (1993) Multiplicity of virus-encoded helper T-cell epitopes expressed on FBL-3 tumor cells. J Virol 67(8):4533-4542

11. Iwashiro M, Messer RJ, Peterson KE, Stromnes IM, Sugie T, Hasenkrug KJ (2001) Immunosuppression by CD4+ regulatory $\mathrm{T}$ cells induced by chronic retroviral infection. Proc Natl Acad Sci USA 98(16):9226-9230. doi:10.1073/pnas.151174198

12. Udono H, Mieno M, Shiku H, Nakayama E (1989) The roles of $\mathrm{CD} 8+$ and CD4+ cells in tumor rejection. Jpn J Cancer Res 80(7):649-654

13. Yoshimura A, Shiku H, Nakayama E (1993) Rejection of an IA+ variant line of FBL-3 leukemia by cytotoxic T lymphocytes with CD4+ and CD4-CD8- T cell receptor-alpha beta phenotypes generated in CD8-depleted C57BL/6 mice. J Immunol 150(11): 4900-4910

14. Lahl K, Loddenkemper C, Drouin C, Freyer J, Arnason J, Eberl G, Hamann A, Wagner H, Huehn J, Sparwasser T (2007) Selective depletion of Foxp $^{+}$regulatory $\mathrm{T}$ cells induces a scurfy-like disease. J Exp Med 204(1):57-63

15. Zelinskyy G, Balkow S, Schimmer S, Werner T, Simon MM, Dittmer U (2007) The level of friend retrovirus replication determines the cytolytic pathway of CD8+ T-cell-mediated pathogen control. J Virol 81(21):11881-11890

16. Zelinskyy G, Dietze KK, Husecken YP, Schimmer S, Nair S, Werner T, Gibbert K, Kershaw O, Gruber AD, Sparwasser T, Dittmer U (2009) The regulatory T-cell response during acute retroviral infection is locally defined and controls the magnitude and duration of the virus-specific cytotoxic T-cell response. Blood 114(15):3199-3207

17. Nair SR, Zelinskyy G, Schimmer S, Gerlach N, Kassiotis G, Dittmer U (2009) Mechanisms of control of acute Friend virus infection by $\mathrm{CD} 4+\mathrm{T}$ helper cells and their functional impairment by regulatory T cells. J Gen Virol 91(Pt 2):440-451. doi:10.1099/ vir.0.015834-0

18. Zelinskyy G, Kraft AR, Schimmer S, Arndt T, Dittmer U (2006) Kinetics of CD8+ effector T cell responses and induced CD4+ regulatory $\mathrm{T}$ cell responses during Friend retrovirus infection. Eur J Immunol 36(10):2658-2670

19. Barber DL, Wherry EJ, Ahmed R (2003) Cutting edge: rapid in vivo killing by memory CD8 T cells. J Immunol 171(1):27-31

20. Schepers K, Toebes M, Sotthewes G, Vyth-Dreese FA, Dellemijn TA, Melief CJ, Ossendorp F, Schumacher TN (2002) Differential kinetics of antigen-specific CD4+ and CD8 + T cell responses in the regression of retrovirus-induced sarcomas. J Immunol 169(6): 3191-3199

21. Chattopadhyay PK, Yu J, Roederer M (2005) De novo expression of CD40L (CD154) identifies antigen-specific CD4+ T-cells that express multiple cytokines. Paper presented at the 12 th conference on retroviruses and opportunistic infections, Boston, Massachusetts, USA

22. Zelinskyy G, Robertson SJ, Schimmer S, Messer RJ, Hasenkrug KJ, Dittmer U (2005) CD8+ T-cell dysfunction due to cytolytic granule deficiency in persistent Friend retrovirus infection. J Virol 79(16):10619-10626
23. Gondek DC, Lu LF, Quezada SA, Sakaguchi S, Noelle RJ (2005) Cutting edge: contact-mediated suppression by CD4+ CD25+ regulatory cells involves a granzyme B-dependent, perforinindependent mechanism. J Immunol 174(4):1783-1786

24. Strauss L, Bergmann C, Whiteside TL (2009) Human circulating CD4+ CD25highFoxp3+ regulatory $\mathrm{T}$ cells kill autologous CD8+ but not CD4+ responder cells by Fas-mediated apoptosis. J Immunol 182(3):1469-1480

25. Getnet D, Grosso JF, Goldberg MV, Harris TJ, Yen HR, Bruno TC, Durham NM, Hipkiss EL, Pyle KJ, Wada S, Pan F, Pardoll DM, Drake CG (2010) A role for the transcription factor Helios in human $\mathrm{CD} 4(+) \mathrm{CD} 25(+)$ regulatory $\mathrm{T}$ cells. Mol Immunol 47(7-8):1595-1600. doi:10.1016/j.molimm.2010.02.001

26. Sugimoto N, Oida $T$, Hirota $K$, Nakamura $K$, Nomura $T$, Uchiyama T, Sakaguchi S (2006) Foxp3-dependent and -independent molecules specific for CD25+ CD4+ regulatory $\mathrm{T}$ cells revealed by DNA microarray analysis. Int Immunol 18(8):11971209. doi:10.1093/intimm/dx1060

27. Greenberg PD (1991) Adoptive T cell therapy of tumors: mechanisms operative in the recognition and elimination of tumor cells. Adv Immunol 49:281-355

28. Mahadevan NR, Rodvold J, Sepulveda H, Rossi S, Drew AF, Zanetti M (2011) Transmission of endoplasmic reticulum stress and pro-inflammation from tumor cells to myeloid cells. Proc Natl Acad Sci USA 108(16):6561-6566. doi:10.1073/pnas.1008 942108

29. Griffith TS, Chin WA, Jackson GC, Lynch DH, Kubin MZ (1998) Intracellular regulation of TRAIL-induced apoptosis in human melanoma cells. J Immunol 161(6):2833-2840

30. Robertson SJ, Ammann CG, Messer RJ, Carmody AB, Myers L, Dittmer U, Nair S, Gerlach N, Evans LH, Cafruny WA, Hasenkrug KJ (2008) Suppression of acute anti-friend virus CD8+ T-cell responses by coinfection with lactate dehydrogenaseelevating virus. J Virol 82(1):408-418. doi:10.1128/JVI.01413-07

31. Vignali DA, Collison LW, Workman CJ (2008) How regulatory $\mathrm{T}$ cells work. Nat Rev Immunol 8(7):523-532. doi:10.1038/ nri2343

32. Curiel TJ, Coukos G, Zou L, Alvarez X, Cheng P, Mottram P, Evdemon-Hogan M, Conejo-Garcia JR, Zhang L, Burow M, Zhu Y, Wei S, Kryczek I, Daniel B, Gordon A, Myers L, Lackner A, Disis ML, Knutson KL, Chen L, Zou W (2004) Specific recruitment of regulatory $\mathrm{T}$ cells in ovarian carcinoma fosters immune privilege and predicts reduced survival. Nat Med 10(9):942-949. doi:10.1038/nm1093

33. Deng L, Zhang H, Luan Y, Zhang J, Xing Q, Dong S, Wu X, Liu $M$, Wang S (2010) Accumulation of foxp3 $+\mathrm{T}$ regulatory cells in draining lymph nodes correlates with disease progression and immune suppression in colorectal cancer patients. Clin Cancer Res 16(16):4105-4112. doi:10.1158/1078-0432.CCR-10-1073

34. Menetrier-Caux C, Gobert M, Caux C (2009) Differences in tumor regulatory $\mathrm{T}$-cell localization and activation status impact patient outcome. Cancer Res 69(20):7895-7898. doi:10.1158/ 0008-5472.CAN-09-1642

35. Zou W (2006) Regulatory T cells, tumour immunity and immunotherapy. Nat Rev Immunol 6(4):295-307. doi:10.1038/nri1806

36. Erdman SE, Rao VP, Olipitz W, Taylor CL, Jackson EA, Levkovich T, Lee CW, Horwitz BH, Fox JG, Ge Z, Poutahidis T (2009) Unifying roles for regulatory $\mathrm{T}$ cells and inflammation in cancer. Int $\mathrm{J}$ Cancer 126(7):1651-1665. doi:10.1002/ijc. 24923

37. Aggarwal BB, Shishodia S, Sandur SK, Pandey MK, Sethi G (2006) Inflammation and cancer: how hot is the link? Biochem Pharmacol 72(11):1605-1621. doi:10.1016/j.bcp.2006.06.029

38. Grossman WJ, Verbsky JW, Barchet W, Colonna M, Atkinson JP, Ley TJ (2004) Human T regulatory cells can use the perforin pathway to cause autologous target cell death. Immunity 21(4):589-601. doi:10.1016/j.immuni.2004.09.002 
39. Cao X, Cai SF, Fehniger TA, Song J, Collins LI, Piwnica-Worms DR, Ley TJ (2007) Granzyme B and perforin are important for regulatory $\mathrm{T}$ cell-mediated suppression of tumor clearance. Immunity 27(4):635-646. doi:10.1016/j.immuni.2007.08.014

40. Dittmer U, He H, Messer RJ, Schimmer S, Olbrich AR, Ohlen C, Greenberg PD, Stromnes IM, Iwashiro M, Sakaguchi S, Evans LH, Peterson KE, Yang G, Hasenkrug KJ (2004) Functional impairment of $\mathrm{CD} 8(+) \mathrm{T}$ cells by regulatory $\mathrm{T}$ cells during persistent retroviral infection. Immunity 20(3):293-303

41. Chaput N, Darrasse-Jeze G, Bergot AS, Cordier C, Ngo-Abdalla S, Klatzmann D, Azogui O (2007) Regulatory T cells prevent CD8 T cell maturation by inhibiting CD4 Th cells at tumor sites. J Immunol 179(8):4969-4978

42. Antony PA, Paulos CM, Ahmadzadeh M, Akpinarli A, Palmer DC, Sato N, Kaiser A, Hinrichs CS, Klebanoff CA, Tagaya Y, Restifo NP (2006) Interleukin-2-dependent mechanisms of tolerance and immunity in vivo. J Immunol 176(9):5255-5266

43. Mempel TR, Pittet MJ, Khazaie K, Weninger W, Weissleder R, von Boehmer H, von Andrian UH (2006) Regulatory T cells reversibly suppress cytotoxic $\mathrm{T}$ cell function independent of effector differentiation. Immunity 25(1):129-141. doi:10.1016/ j.immuni.2006.04.015

44. Tang Q, Adams JY, Tooley AJ, Bi M, Fife BT, Serra P, Santamaria P, Locksley RM, Krummel MF, Bluestone JA (2006) Visualizing regulatory $\mathrm{T}$ cell control of autoimmune responses in nonobese diabetic mice. Nat Immunol 7(1):83-92. doi:10.1038/ni1289

45. Kim J, Lahl K, Hori S, Loddenkemper C, Chaudhry A, deRoos P, Rudensky A, Sparwasser T (2009) Cutting edge: depletion of Foxp3+ cells leads to induction of autoimmunity by specific ablation of regulatory $\mathrm{T}$ cells in genetically targeted mice. J Immunol 183(12):7631-7634. doi:10.4049/jimmunol.0804308

46. Klages K, Mayer CT, Lahl K, Loddenkemper C, Teng MW, Ngiow SF, Smyth MJ, Hamann A, Huehn J, Sparwasser T (2010) Selective depletion of Foxp3 + regulatory T cells improves effective therapeutic vaccination against established melanoma. Cancer Res 70(20):7788-7799. doi:10.1158/0008-5472.CAN-10-1736

47. Kiniwa Y, Miyahara Y, Wang HY, Peng W, Peng G, Wheeler TM, Thompson TC, Old LJ, Wang RF (2007) CD8+ Foxp3+ regulatory $\mathrm{T}$ cells mediate immunosuppression in prostate cancer. Clin Cancer Res 13(23):6947-6958. doi:10.1158/1078-0432.CCR-07-0842

48. Afonina IS, Cullen SP, Martin SJ (2010) Cytotoxic and noncytotoxic roles of the CTL/NK protease granzyme B. Immunol Rev 235(1):105-116. doi:10.1111/j.0105-2896.2010.00908.x

49. Perez-Diez A, Joncker NT, Choi K, Chan WF, Anderson CC, Lantz O, Matzinger P (2007) CD4 cells can be more efficient at tumor rejection than CD8 cells. Blood 109(12):5346-5354. doi: 10.1182/blood-2006-10-051318

50. Corthay A (2007) CD4+ T cells cooperate with macrophages for specific elimination of MHC class II-negative cancer cells. Adv Exp Med Biol 590:195-208. doi:10.1007/978-0-387-34814-8_14

51. Greenberg PD, Kern DE, Cheever MA (1985) Therapy of disseminated murine leukemia with cyclophosphamide and immune Lyt-1+,2- T cells. Tumor eradication does not require participation of cytotoxic T cells. J Exp Med 161(5):1122-1134

52. Sojka DK, Fowell DJ (2011) Regulatory T cells inhibit acute IFN-gamma synthesis without blocking T-helper cell type 1 (Th1) differentiation via a compartmentalized requirement for IL10. Proc Natl Acad Sci USA 108(45):18336-18341. doi: 10.1073/pnas.1110566108

53. Hegde NR, Dunn C, Lewinsohn DM, Jarvis MA, Nelson JA, Johnson DC (2005) Endogenous human cytomegalovirus $\mathrm{gB}$ is presented efficiently by MHC class II molecules to CD4+ CTL. J Exp Med 202(8):1109-1119. doi:10.1084/jem.20050162

54. Heller KN, Gurer C, Munz C (2006) Virus-specific CD4+ T cells: ready for direct attack. J Exp Med 203(4):805-808. doi: $10.1084 /$ jem.20060215
55. Paludan C, Bickham K, Nikiforow S, Tsang ML, Goodman K, Hanekom WA, Fonteneau JF, Stevanovic S, Munz C (2002) Epstein-Barr nuclear antigen 1-specific CD4(+) Th1 cells kill Burkitt's lymphoma cells. J Immunol 169(3):1593-1603

56. Holloway PA, Kaldenhoven N, Kok-Schoemaker HM, Dijk M, Otten HG, Tilanus M, Postma S, Mutis T, Lokhorst HM, Bloem AC (2005) A class II-restricted cytotoxic T-cell clone recognizes a human minor histocompatibility antigen with a restricted tissue distribution. Br J Haematol 128(1):73-81. doi:10.1111/j.13652141.2004.05283.x

57. Quezada SA, Simpson TR, Peggs KS, Merghoub T, Vider J, Fan X, Blasberg R, Yagita H, Muranski P, Antony PA, Restifo NP, Allison JP (2010) Tumor-reactive CD4(+) T cells develop cytotoxic activity and eradicate large established melanoma after transfer into lymphopenic hosts. J Exp Med 207(3):637-650. doi: 10.1084/jem.20091918

58. Spaapen RM, Lokhorst HM, van den Oudenalder K, Otterud BE, Dolstra H, Leppert MF, Minnema MC, Bloem AC, Mutis T (2008) Toward targeting B cell cancers with CD4+ CTLs: identification of a CD19-encoded minor histocompatibility antigen using a novel genome-wide analysis. J Exp Med 205(12): 2863-2872. doi:10.1084/jem.20080713

59. Hunder NN, Wallen H, Cao J, Hendricks DW, Reilly JZ, Rodmyre R, Jungbluth A, Gnjatic S, Thompson JA, Yee C (2008) Treatment of metastatic melanoma with autologous CD4+ T cells against NY-ESO-1. N Engl J Med 358(25):2698-2703. doi: 10.1056/NEJMoa0800251

60. Ganss R, Ryschich E, Klar E, Arnold B, Hammerling GJ (2002) Combination of $\mathrm{T}$-cell therapy and trigger of inflammation induces remodeling of the vasculature and tumor eradication. Cancer Res 62(5):1462-1470

61. Lugade AA, Moran JP, Gerber SA, Rose RC, Frelinger JG, Lord EM (2005) Local radiation therapy of B16 melanoma tumors increases the generation of tumor antigen-specific effector cells that traffic to the tumor. J Immunol 174(12):7516-7523

62. Ossendorp F, Mengede E, Camps M, Filius R, Melief CJ (1998) Specific $\mathrm{T}$ helper cell requirement for optimal induction of cytotoxic $\mathrm{T}$ lymphocytes against major histocompatibility complex class II negative tumors. J Exp Med 187(5):693-702

63. Spiotto MT, Rowley DA, Schreiber H (2004) Bystander elimination of antigen loss variants in established tumors. Nat Med 10(3):294-298. doi:10.1038/nm999

64. Mantovani A, Sica A, Sozzani S, Allavena P, Vecchi A, Locati M (2004) The chemokine system in diverse forms of macrophage activation and polarization. Trends Immunol 25(12):677-686. doi:10.1016/j.it.2004.09.015

65. Huang Y, Erdmann N, Peng H, Herek S, Davis JS, Luo X, Ikezu T, Zheng J (2006) TRAIL-mediated apoptosis in HIV-1-infected macrophages is dependent on the inhibition of Akt-1 phosphorylation. J Immunol 177(4):2304-2313

66. Brocker EB, Suter L, Sorg C (1984) HLA-DR antigen expression in primary melanomas of the skin. J Invest Dermatol 82(3): 244-247

67. Walsh MD, Dent OF, Young JP, Wright CM, Barker MA, Leggett BA, Bokey L, Chapuis PH, Jass JR, Macdonald GA (2009) HLA-DR expression is associated with better prognosis in sporadic Australian clinicopathological Stage C colorectal cancers. Int J Cancer 125(5):1231-1237. doi:10.1002/ijc.24484

68. Friedman KM, Prieto PA, Devillier LE, Gross CA, Yang JC, Wunderlich JR, Rosenberg SA, Dudley ME (2012) Tumor-specific CD4+ melanoma tumor-infiltrating lymphocytes. J Immunother 35(5):400-408. doi:10.1097/CJI.0b013e31825898c5

69. Finney HM, Akbar AN, Lawson AD (2004) Activation of resting human primary $\mathrm{T}$ cells with chimeric receptors: costimulation from CD28, inducible costimulator, CD134, and CD137 in series with signals from the TCR zeta chain. J Immunol 172(1):104-113 